\title{
Belgium: 2006 Article IV Consultation-Staff Report; and Public Information Notice on the Executive Board Discussion
}

Under Article IV of the IMF's Articles of Agreement, the IMF holds bilateral discussions with members, usually every year. In the context of the 2006 Article IV consultation with Belgium, the following documents have been released and are included in this package:

- $\quad$ the staff report for the 2006 Article IV consultation, prepared by a staff team of the IMF, following discussions that ended on November 13, 2006, with the officials of Belgium on economic developments and policies. Based on information available at the time of these discussions, the staff report was completed on January 8, 2007. The views expressed in the staff report are those of the staff team and do not necessarily reflect the views of the Executive Board of the IMF.

- $\quad$ a Public Information Notice (PIN) summarizing the views of the Executive Board as expressed during its February 16, 2007 discussion of the staff report that concluded the Article IV consultation.

The document listed below has been or will be separately released.

\section{Selected Issues Paper}

The policy of publication of staff reports and other documents allows for the deletion of market-sensitive information.

To assist the IMF in evaluating the publication policy, reader comments are invited and may be sent by e-mail to publicationpolicy@imf.org.

$$
\begin{gathered}
\text { Copies of this report are available to the public from } \\
\text { International Monetary Fund • Publication Services } \\
70019^{\text {th }} \text { Street, N.W. • Washington, D.C. } 20431 \\
\text { Telephone: (202) 623-7430 • Telefax: (202) 623-7201 } \\
\text { E-mail: publications@imf.org • Internet: http://www.imf.org }
\end{gathered}
$$

Price: $\$ 18.00$ a copy

\section{International Monetary Fund Washington, D.C.}



INTERNATIONAL MONETARY FUND

BELGIUM

\section{Staff Report for the 2006 Article IV Consultation}

Prepared by Staff Representatives for the 2006 Consultation with Belgium

Approved by Ajai Chopra and Michael Hadjimichael

January 8, 2007

\section{EXECUTIVE SUMMARY}

Sound policies have underpinned Belgium's recent favorable economic performance, but their further strengthening is necessary to meet the challenges posed by globalization, aging, fiscal federalism, and the increasing complexity of the financial sector. There is general recognition that fiscal consolidation and further labor market reforms are key ingredients of the solution, but the authorities anticipate a lengthy process of consensusbuilding and gradual action. In the staff's view, speed, depth, and coordination of policy implementation across all levels of government need to be stepped up.

Barring major shocks to the international environment, economic growth is projected to slow from nearly 3 percent in 2006 to a robust 2.2 percent in 2007. Labor unions, employers, and the authorities agreed that the trend erosion in competitiveness had to be halted and that the stubbornly high unemployment rate called for wage moderation and strict execution of the Generation Pact.

The financial system has gained further resilience, and supervisors have made major strides in improving the already high quality of supervision in line with the recommendations of the 2005 FSAP. The trend toward internationalization of financial institutions and their expansion in nontraditional areas is modifying the systemic risk profile of the financial system.

Supervisors acknowledged that they will have to sharpen the focus of their resources on these developments and underscored the need for international cooperation.

Consistent with the strategy to deal with aging, the 2007 budget sets in motion the muchneeded buildup of fiscal surpluses, though some additional measures are likely to be required to achieve the target. Moreover, medium-term consolidation objectives will have to be more ambitious than envisaged and backed by a specific strategy of expenditure restraint. There was agreement that revising fiscal federalism arrangements had become a priority and that fiscal institutions had to be strengthened. Following the Generation Pact, there is no appetite for the more comprehensive package of labor market reforms recommended by the staff. 


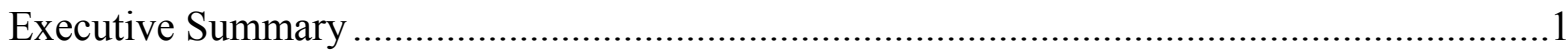

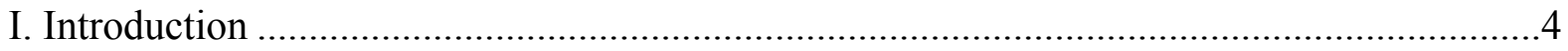

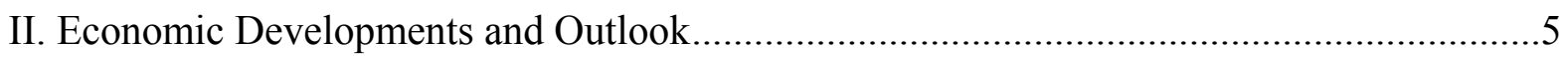

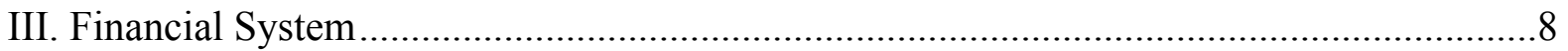

IV. Dealing With Aging and Globalization ............................................................. 10

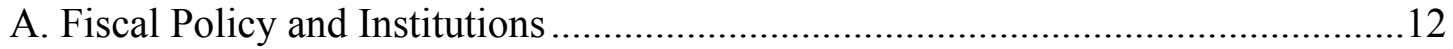

B. Employment Creation and Productivity Growth................................................16

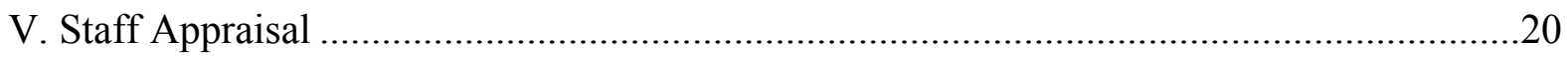

Tables

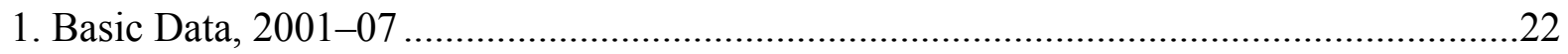

2. Indicators of External and Financial Vulnerability, 2000-06 .......................................24

3. Financial Soundness Indicators of the Banking Sector, 1999-2006 ...............................25

4. Financial Soundness Indicators of the Nonbanking Sectors, 1999-2006.........................27

5. Operations of the General Government, 1999-2005 ..................................................28

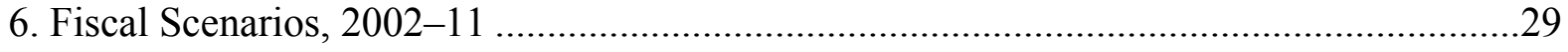

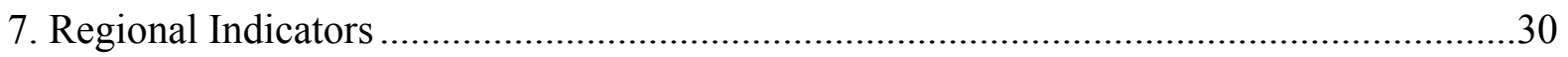

Figures

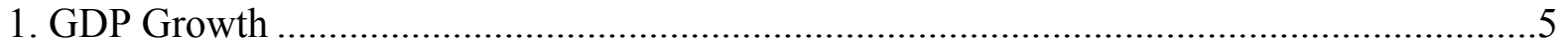

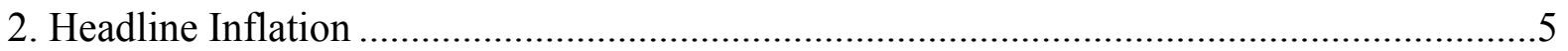

3. Policy Conditions........................................................................................................

4. Residential Investment and House Prices ....................................................................6

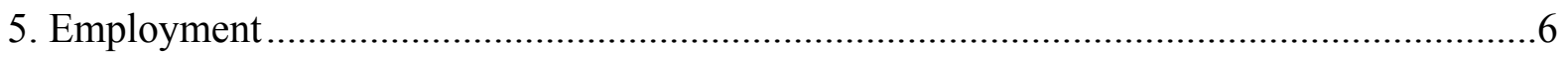

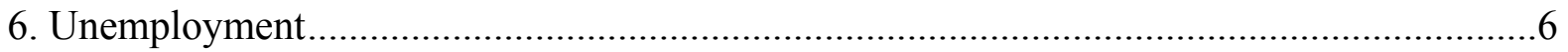

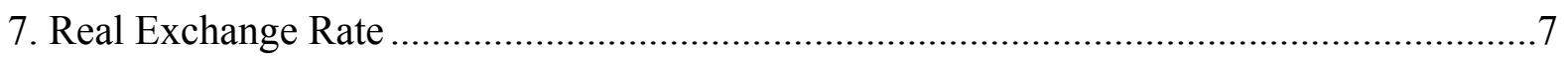

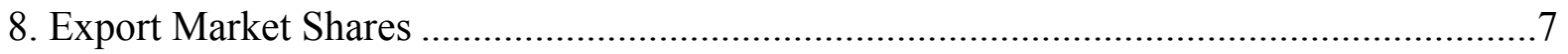

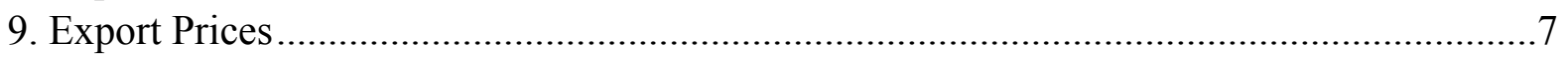

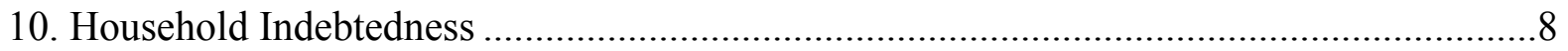

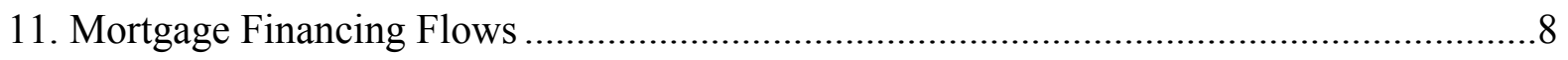

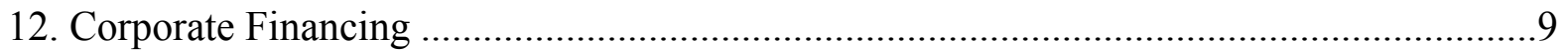

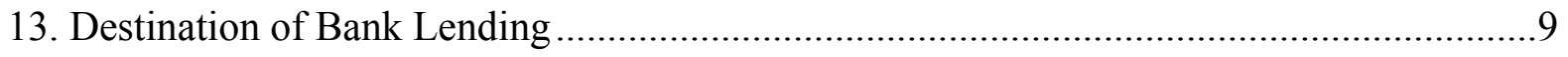

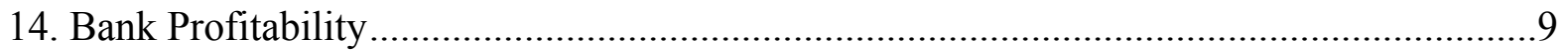

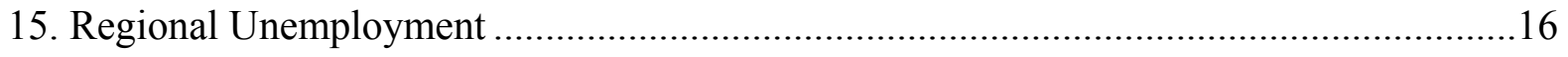


Boxes

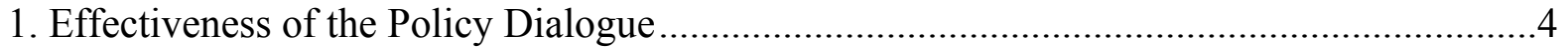

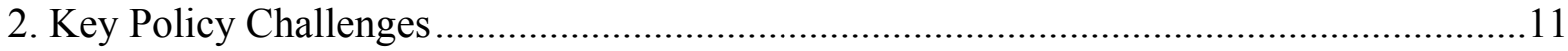

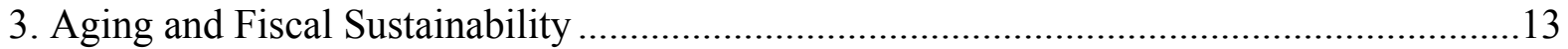

4. Wage Formation and External Competitiveness............................................................ 18

Appendixes

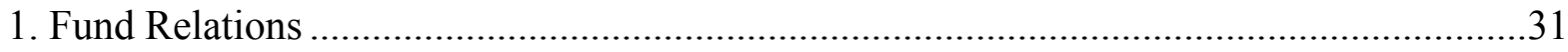

2. Statistical Issues and Table of Common Indicators........................................................34 


\section{INTRODUCTION ${ }^{1}$}

\section{Fiscal consolidation, job creation, and further strengthening of financial} supervision are policy priorities for Belgium. They correspond to the challenges of dealing with rising aging costs and fiscal federalism, taking full advantage of the global expansion, and adapting supervision to an increasingly complex and internationally-oriented financial sector. Overall, the economy has performed well, and policy objectives have been in line with Fund recommendations, but implementation has lacked determination in some key areas (Box 1). Hence, following the mid-2007 elections, a decisive strengthening of policies will be crucial to preserve high living standards and an adequate social security system.

\section{Box 1. Effectiveness of the Policy Dialogue}

The authorities agree that policies should focus on raising employment rates and achieving fiscal consolidation. Implementation of Fund recommendations has been slow and remains incomplete, partly because the scope and speed of reform are constrained by the long-standing tradition of consensusbuilding and the complex federal structure of government. The authorities see continuous and comprehensive engagement of the Fund as key to its effectiveness.

\section{Fiscal policy}

Fund recommendations: reduce primary spending growth durably to achieve the authorities' twin objectives of fiscal consolidation and tax reduction; adopt a multi-year expenditure-based framework to lock in fiscal adjustment; revise the fiscal federalism arrangements and reinforce fiscal institutions, including the internal stability pact and the High Council of Finance (HCF).

Policy developments: the budget has been balanced or in surplus since $2000^{1}$ with public debt steadily falling as a share of GDP. However, interest savings have been used for tax cuts and spending hikes, leading to an erosion of the primary surplus. Primary spending growth remains too high for consolidation. The authorities continue to focus on achieving nominal balance targets. The HCF has resumed its work.

\section{Labor and product market reforms}

Fund recommendations: phase out early retirement arrangements, modify the wage-bargaining framework, shorten the duration of unemployment benefits, and enforce job search requirements; in product markets, continue deregulation and liberalization.

Policy developments: reforms have relied mostly on active labor market programs, but recently, employment services have been strengthened. The Generation Pact set out measures to raise employment of the young and old. Social partners prefer maintaining the central wage-bargaining framework, but some flexibility has become acceptable. Product market reforms are proceeding along EU timelines, and the administrative burden was reduced appreciably.

\section{Financial sector}

Fund recommendations: the 2005 FSAP recommended adapting supervisory arrangements to changing market developments, enhancing macro-prudential supervision and cooperation between the central bank and supervisors, upgrading insurance supervision, and strengthening pension supervision earnestly. Policy developments: most of the recommendations have been implemented.

${ }^{1}$ Though this is disputed by Eurostat for 2005.

\footnotetext{
${ }^{1}$ Mission details are in Appendix I on Fund Relations.
} 


\section{ECONOMIC DEVELOPMENTS AND OUTLOOK}

2. The economic upturn that started in mid-2005 has remained on track. On the heels of a catch-up in private investment, the revival of private consumption and the cyclical expansion in neighboring countries have broadened the recovery to all sectors of the economy and allowed growth to become more balanced in 2006 (Table 1). ${ }^{2}$ Owing to more robust private and public consumption, growth has been exceeding that of key trading partners (Figure 1), and the economy is now operating near capacity.

\section{Underlying inflation has been stable and broadly}

in line with the euro area average. Deviations have been due to administrative price changes and recently to a methodological revision (Figure 2). ${ }^{3}$ Headline inflation has been more volatile, reflecting the higher weight of energy prices, with the decline in the latter pushing it toward 2 percent at end-2006. Inflationary pressures from widespread wage indexation have been muted: the relevant index rose by only 1.7 percent in 2006, as it largely excludes energy prices and benefited from the correction of a previous upward bias.

\section{Monetary conditions have been supportive, while} fiscal policy turned procyclical in 2006 (Figure 3). Despite some real appreciation and interest rate hikes, monetary conditions have remained accommodating, only recently reaching their long-run average. With the cycle typically well attuned to the euro area average, interest rates set by the ECB have been suitable from Belgium's perspective. Guided by nominal targets, fiscal policy imparted an impulse of almost 1 percentage point of GDP in 2006, as growth surprised on the upside. While acknowledging the small fiscal multiplier, owing to the highly open nature of the economy, and the confidence-enhancing effect of sustained achievement of fiscal targets, the staff saw this as a key factor underpinning
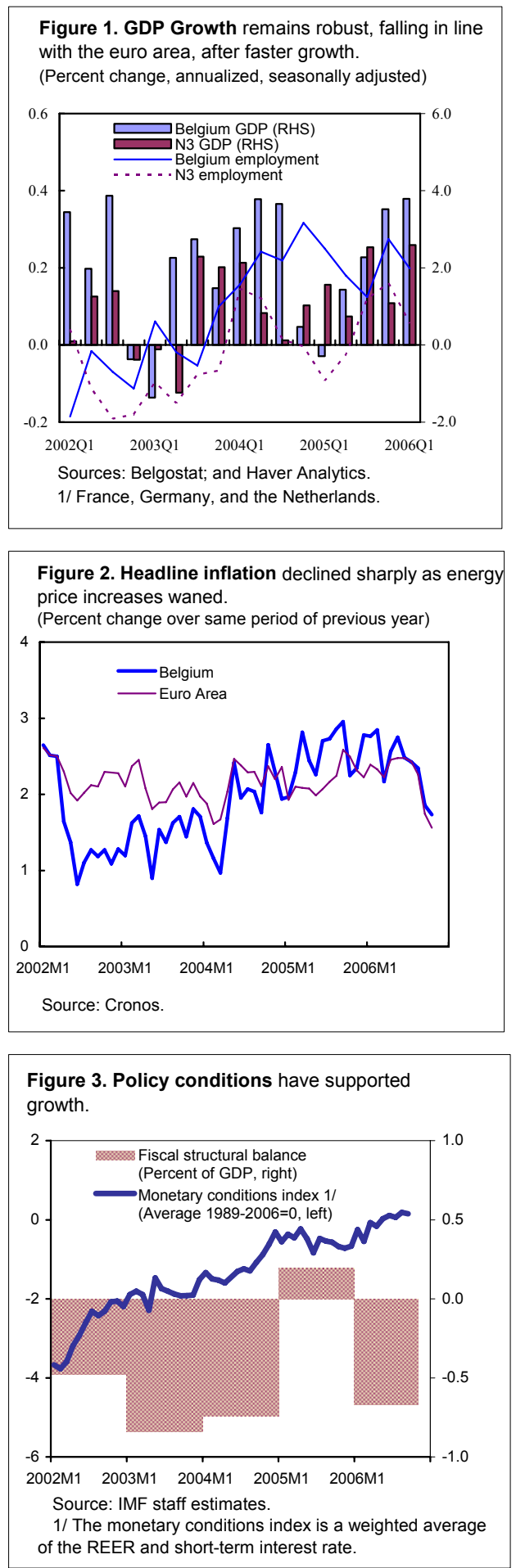

${ }^{2}$ In 2006, national accounts switched to chain weighting. Changes were minor but indicate a slightly larger external contribution to growth (see Appendix II).

${ }^{3}$ A revision in the tourism component shifted the seasonal pattern. 
the strength of activity. The authorities, though, felt that their policy of tax cuts in a balanced budget environment had been more important.

\section{Buoyant house prices have bolstered residential} investment and supported household spending (Figure 4). Residential real estate prices registered double-digit growth in 2005 , for the second consecutive year, but the market has cooled since then, with realtor associations expecting the pace of increases to be halved in $2006 .{ }^{4}$ While a strong housing market is a feature common to many euro area countries, domestic factors have been adding exuberance: the 2004 fiscal amnesty led to a repatriation of assets that were invested in secondary residences, and reduced transaction costs and strengthened fiscal incentives for firsthome purchases boosted family house prices from 2005 onward. Some indicators (e.g., the ratio of disposable income over monthly mortgage payments) suggest a slight overvaluation of the market since end-2005, but the price level remains below that of neighboring countries. The impact on activity has been felt through residential construction and mortgage refinancing, as the household savings rate has remained stable for the past three years.

\section{At odds with developments elsewhere in the euro} area, the unemployment rate has not declined significantly (Figures 5 and 6). Comparatively faster labor force growth, high relative labor costs, and less wage moderation seem to be the underlying culprits, though labor unions saw a lack of training and a less dynamic structure of production as equally important factors. All job creation since mid-2005, which has not lagged much compared to previous cycles, has been in the nontradable sectors, with losses in industry not quite matched by gains in construction. More labor hoarding and the fitful start to the current recovery appear to have dampened the cyclicality of unemployment. Finally, a recent tightening of job search requirements-
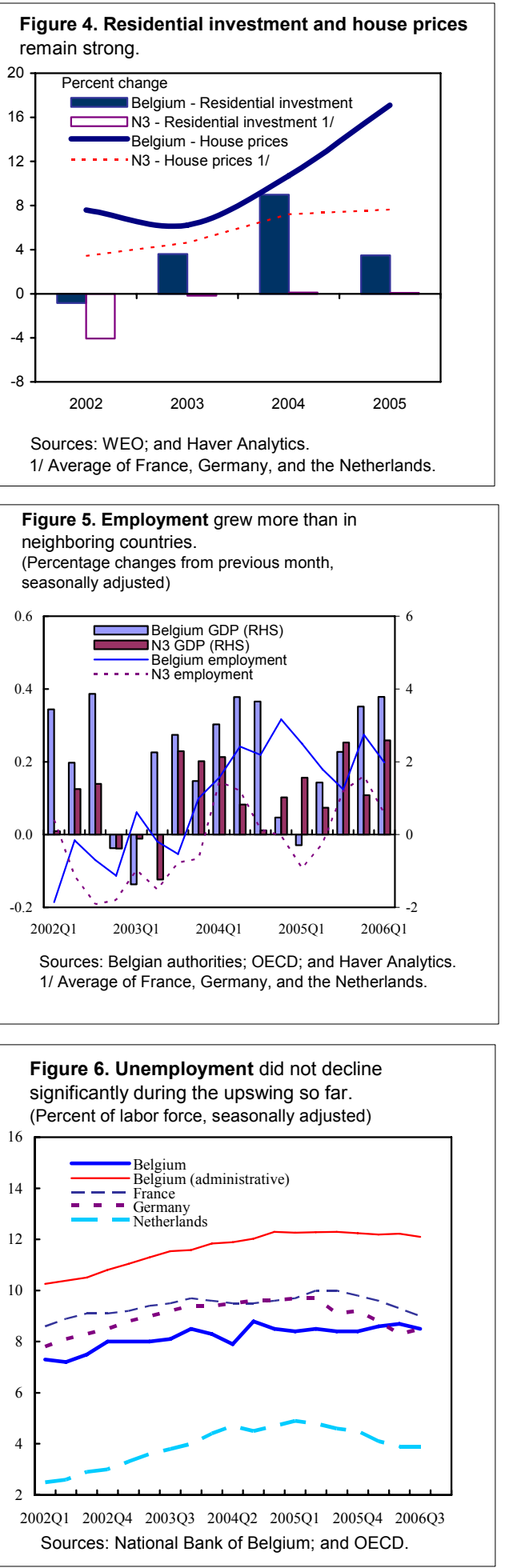

\footnotetext{
${ }^{4}$ House price indices are not corrected for quality, however, which seems to have been steadily rising.
} 
which has reduced the administrative unemployment rate slightly - seems to have spurred more people into active job search, but the authorities agreed that it was too early to declare success.

\section{While judging its current level to be} appropriate, all agreed that competitiveness should not be allowed to erode further (Figure 7). As the authorities underscored, developments in relative unit labor costs and market share volumes were similar to elsewhere, except in Germany. Current account and trade surpluses had been sustained, with their recent decline mainly the result of adverse terms of trade effects. The economy has remained attractive to foreign investors because of progress in reducing business regulation and corporate income taxation. In addition, model-based estimates suggest that the current exchange rate is not overvalued. Nonetheless, with labor costs (and productivity) among the highest in the world, and several manufacturing sectors wilting under competitive pressure, the authorities and social partners agreed that wage moderation would be essential going forward.

\section{Export volume shares have fallen} appreciably, but value shares have held up well (Figure 8). Even though exporters do not seem to have comparatively greater pricing power, given the preponderance of standardized products, price deflators for exports (and to a lesser extent, imports) appear to be consistently outpacing those of trading partners (Figure 9). There is also no evidence that the product structure has been shifting toward higher value-added products. This raises suspicions of a statistical bias in the price-volume breakdown of trade, whose correction would, however, not materially alter the assessment of overall performance.

\section{Against this background, economic growth is} expected to slow but maintain a robust pace. The authorities and the staff project GDP growth to decline from nearly 3 percent in 2006 to 2.2 percent in 2007 , as rising interest rates dampen demand, residential construction eases from its recent sustained vigorous pace,

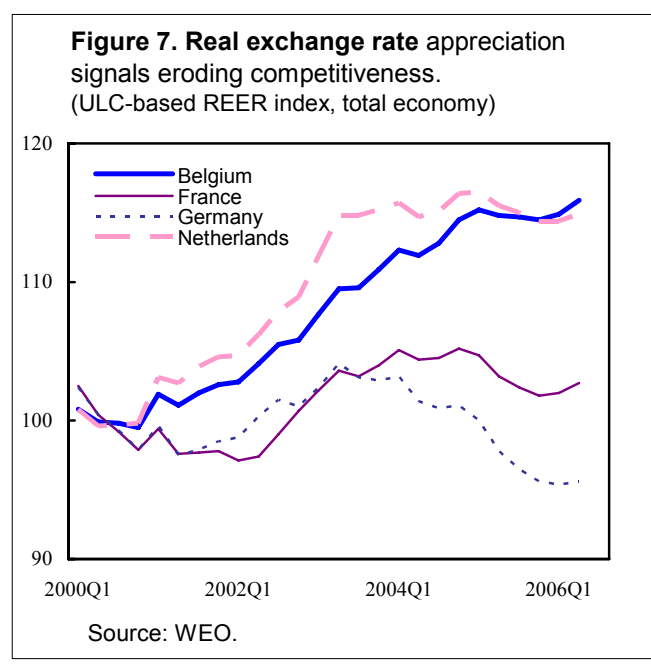

Figure 8. Export market shares have fallen in volume but hardly in value.

(Percent of partner imports, NA-based)

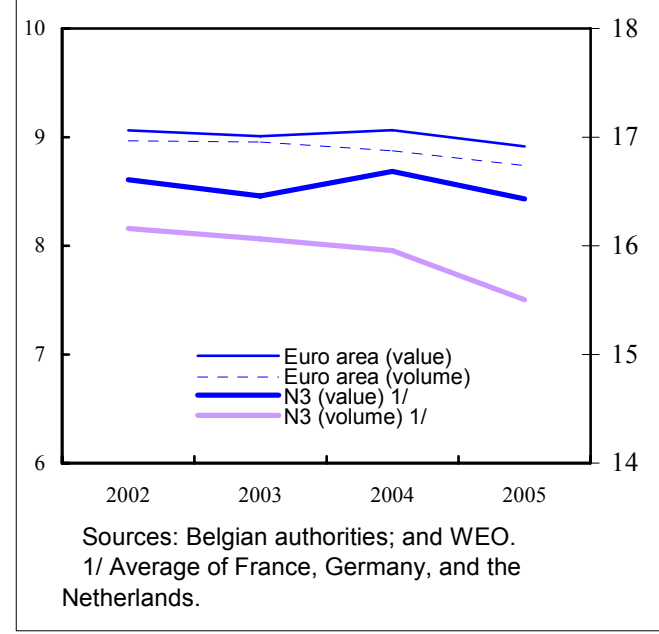

Figure 9. Export prices suggest suspiciously strong pricing power.

(Export deflator, NA-based, 2001=100)

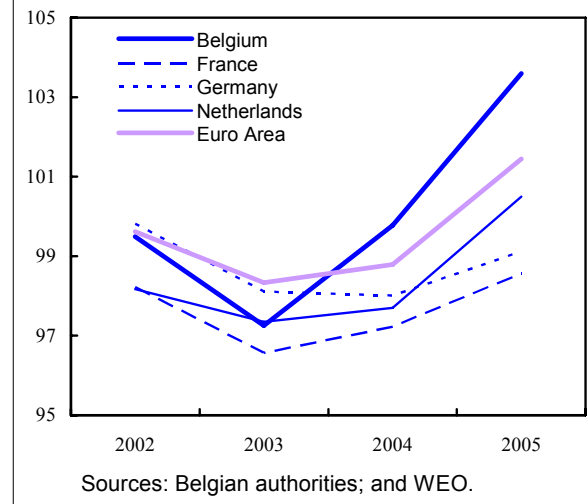


the fiscal stance turns restrictive, and the global environment softens. With good profitability and high capacity utilization rates, private investment should remain strong, but - after its substantial catch-up during 2004-05-will register slower growth. There was agreement that abrupt euro appreciation associated with a disorderly resolution of global imbalances and a sharper-than-expected U.S. slowdown constitute key downside risks, and that the German economy could go either way from the baseline projecting a slowing associated with an increase in the VAT rate. ${ }^{5}$ On the domestic front, residential construction could surprise on the upside. Inflation is projected to reach nearly 2 percent in 2007, in part due to mid-year indirect tax increases.

\section{FinANCIAL SySTEM}

\section{Households are benefiting from the ongoing}

financial deepening. They are adding about 2 percent of GDP per year to their large stock of net financial assets, which are generally viewed as retirement savings since specific third pillar pension savings vehicles are only beginning to emerge. In search of return, households have been increasing their claims on institutional investors. This shift has been accompanied by a rise in the risks borne by households and fostered by a larger supply of more flexible mutual fund and insurance products, and a rise in the taxation of income from securities. On the liability side, mortgage credit, the largest household source of credit, has been steadily growing since the late 1980 s, recently boosted by low interest rates and the booming house market (Figure 10). Banks have allowed households to swiftly take advantage of changes in the level and term structure of interest rates (Figure 11). They have introduced new instruments with different risk and price profiles, but there is no evidence of any loosening of lending standards.
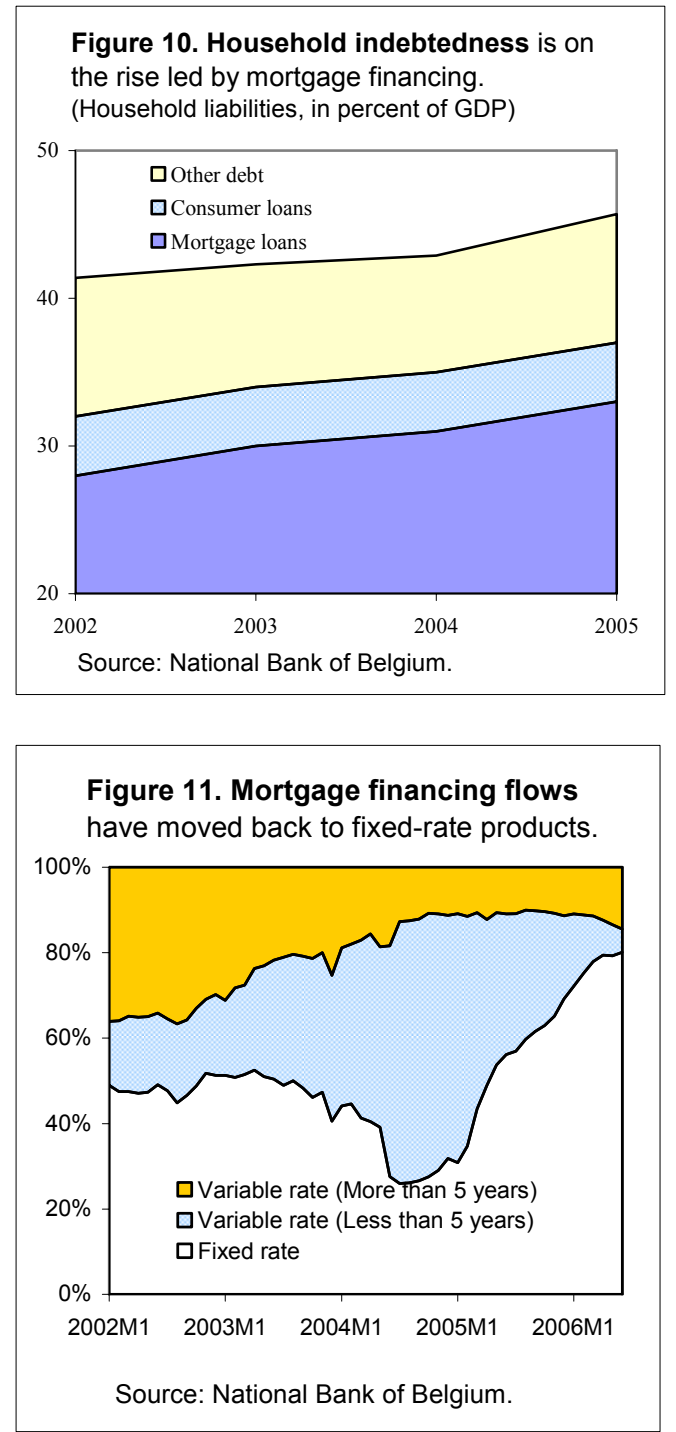

${ }^{5}$ See IMF Country Report No. 06/436, which indicates that spillovers are modest (http://www.imf.org/external/pubs/ft/scr/2006/cr06436.pdf). 


\section{Corporate deleveraging is continuing, with the}

\section{financial sector intermediating the shift toward equity}

finance (Figure 12). As elsewhere, profit margins of nonfinancial corporations have risen, generating the internal funds needed to finance the upswing in investment.

Concurrently, recourse to external financing has increasingly taken the form of equity issues, slightly more than in other countries, as a duty on new equity issues was eliminated and an allowance for corporate equity (ACE) instituted.

Consequently, debt financing turned negative in 2005 for the first time in several years, and equity issuance skyrocketed in 2006. Venture capital seems to be in sufficient supply but remains undersized as the economy is insufficiently geared toward innovation and small entrepreneurship.

\section{The trend toward internationalization of financial} institutions has been accelerating, while banks are expanding in nontraditional areas. No doubt, the fact that two of the four largest banks are cross-border institutions is a driving factor, but other banks are also raising their exposures abroad, especially to Central and Eastern Europe. The share of domestic customers has fallen to about one third of bank assets, and lending to non-euro area residents has been one of the fastest growing activities (Figure 13). At present, half of the corporate loans are to residents outside of the euro area. In addition, banks have branched out into energy trading and have been engaging increasingly with hedge funds, mostly on behalf of clients and with transfer of collateral so that their capital at risk in these operations has remained limited.

\section{The financial system has remained stable and highly profitable, liquid, and solvent (Figure 14,} Tables 2-4). Benefiting from a benign risk environment, low interest rates and effervescent equity markets, bank-insurance groups are experiencing high returns on assets and equity, in part due to historically low levels of provisioning and nonperforming loans. Banks remain well capitalized with risk asset ratios reaching close to 12 percent in mid-2006. Solvency and coverage ratios of insurance companies and pension funds have been increasing due to exceptional

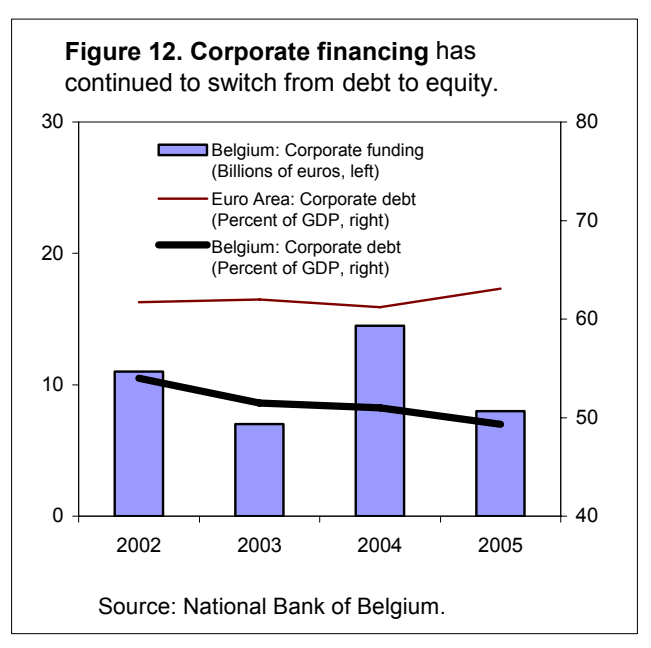

Figure 13. Destination of bank lending is shifting abroad, in search of higher yields.

(Credit destination as a percent of total lending)

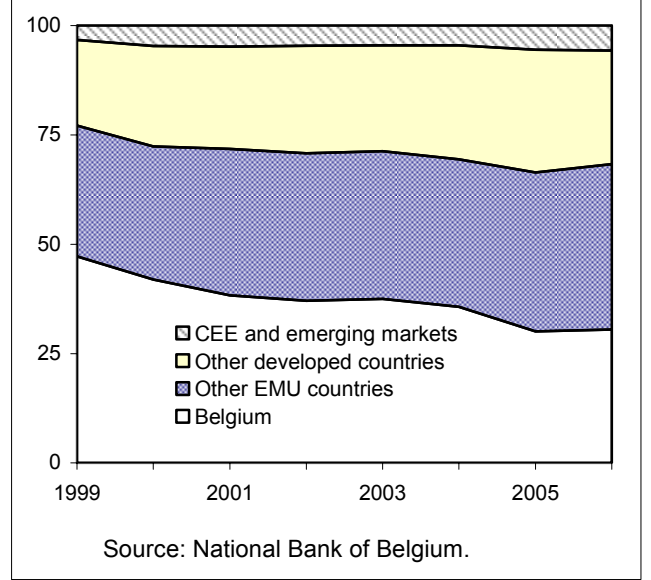

Figure 14. Bank profitability has continued to recover and is approaching historical highs.

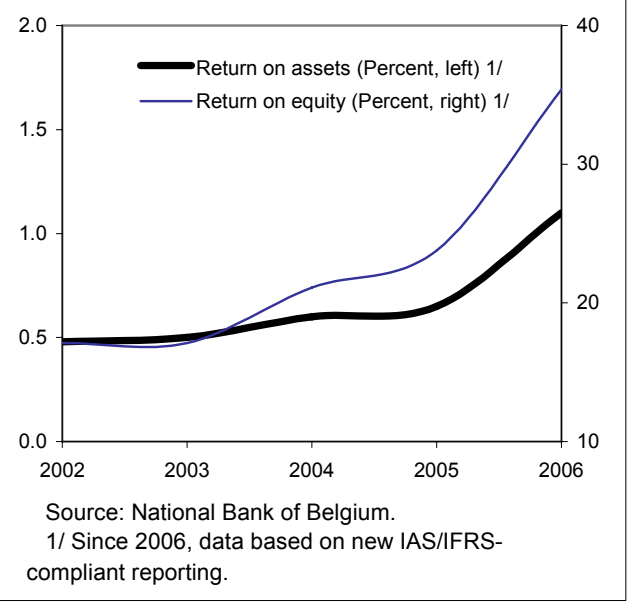


growth in premiums in 2005, in anticipation of higher taxation, and rising equity valuations. Stress tests conducted by the Financial Stability Committee show the system to be resilient to plausible shocks, confirming the findings of the 2005 financial stability assessment by the IMF (FSAP). ${ }^{6}$

14. In line with the FSAP recommendations, the unified supervisor (CBFA) and the central bank (NBB) have been substantially improving the quality of supervision, from an already high level. In particular, regulations and supervision in banking, insurance, securities, payments, and settlement have been fully aligned with international standards, pension fund and insurance supervision upgraded, and internal controls and operation of the CBFA and cooperation between the CBFA and the NBB improved. The staff urged the authorities to accelerate the envisaged on-site exams of pension funds and conduct more outreach on the new pension law. The authorities acknowledged these points as well as the need to further exploit the synergies between the CBFA and the NBB.

\section{Looking ahead, it was agreed that supervisors need to adapt to the changing} systemic risk profile of the bank-insurance groups. Given resource constraints, the staff called for a risk-based approach to the allocation of management and staff resources at the CBFA. The authorities saw merit in this suggestion but felt that reputational and legal considerations required a continuous and comprehensive engagement with firms of lesser systemic importance. Beyond improving international cooperation through memoranda of understanding with foreign supervisors, the authorities argued for the establishment of an international tier to supervision for regionally and globally systemic institutions. In this context, they remain committed to addressing the international dimension of crisis management, including solvency issues, and to proactively securing a high level of engagement with international partners on the Euroclear payments and settlement system.

\section{Dealing With Aging and Globalization ${ }^{7}$}

16. The authorities and the public generally recognize that meeting the challenge of aging in the context of globalization requires a comprehensive strategy, but in the staff's view, speed, depth, and specificity of policy implementation are lagging. The key components of the authorities' strategy consist of fiscal consolidation to benefit from interest savings associated with a declining public debt burden, and a sharp increase in employment rates. On both counts, the authorities have made good progress, but success is still distant, and key opportunities have not been exploited (Box 2). Achieving balanced budgets or small

\footnotetext{
${ }^{6}$ FSSA, IMF Country Report 06/75: http://www.imf.org/external/pubs/ft/scr/2006/cr0675.pdf.

${ }^{7}$ A Selected Issues Chapter "Fiscal Sustainability and Coordination in a Federal Structure" provides detailed background information for this section.
} 


\section{Box 2. Belgium: Key Policy Challenges}

\section{Labor Market:}

\section{Raising employment rates,}

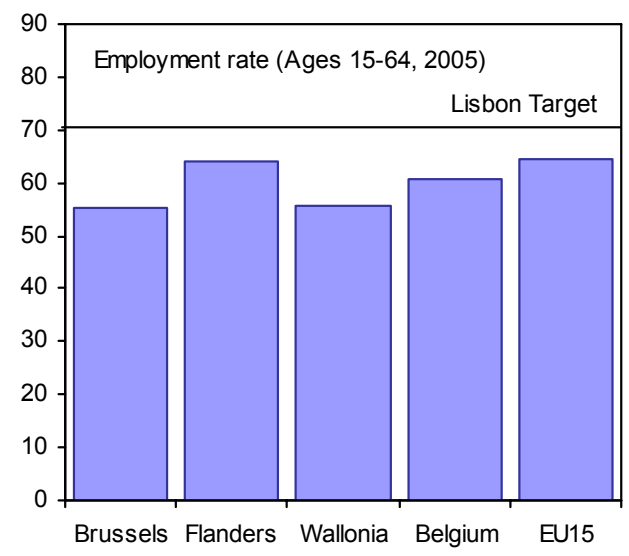

...especially for the older...

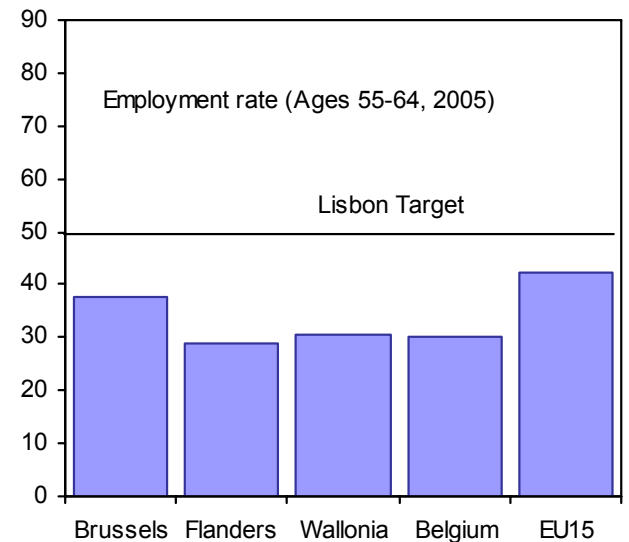

...and for women.

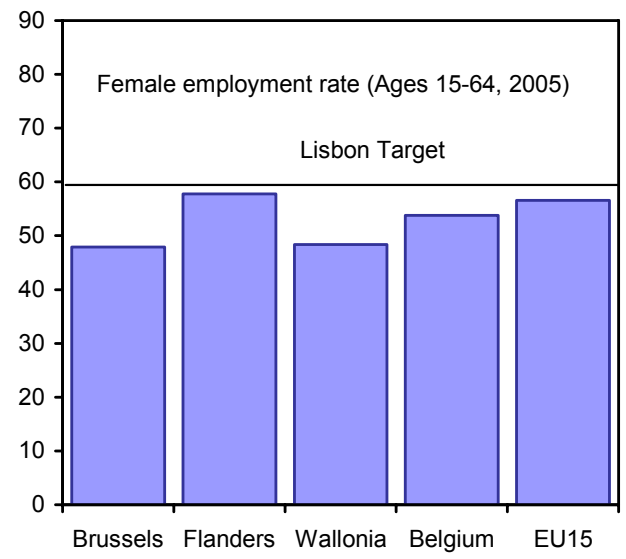

Fiscal Policy:

Building up structural primary surpluses,

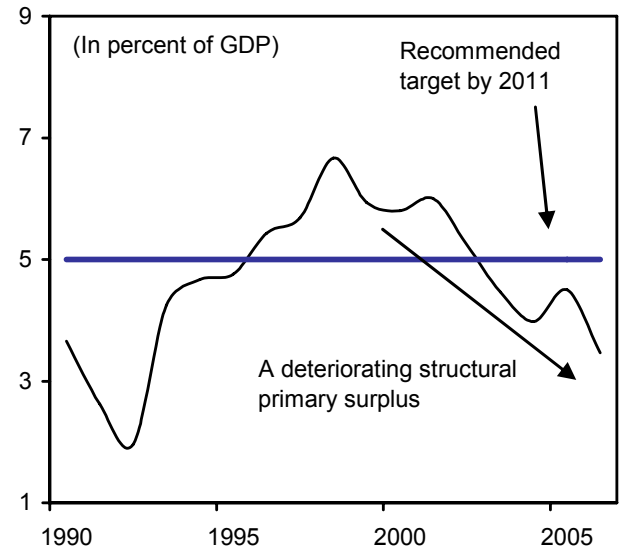

further reducing public debt, and

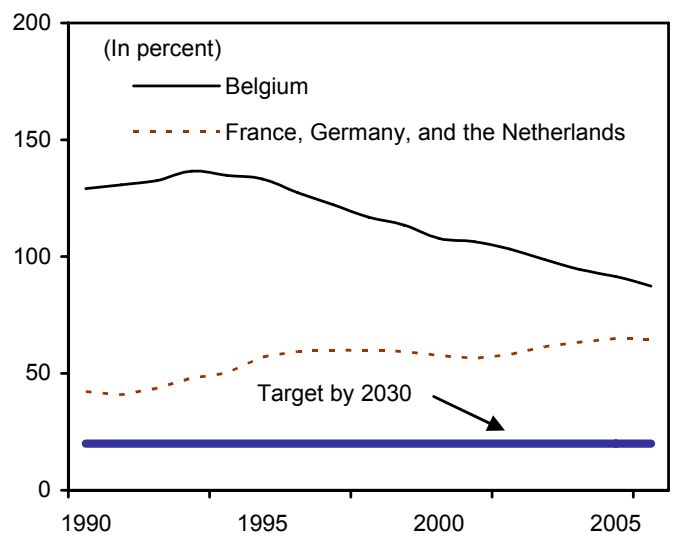

resolving fiscal federalism tensions.

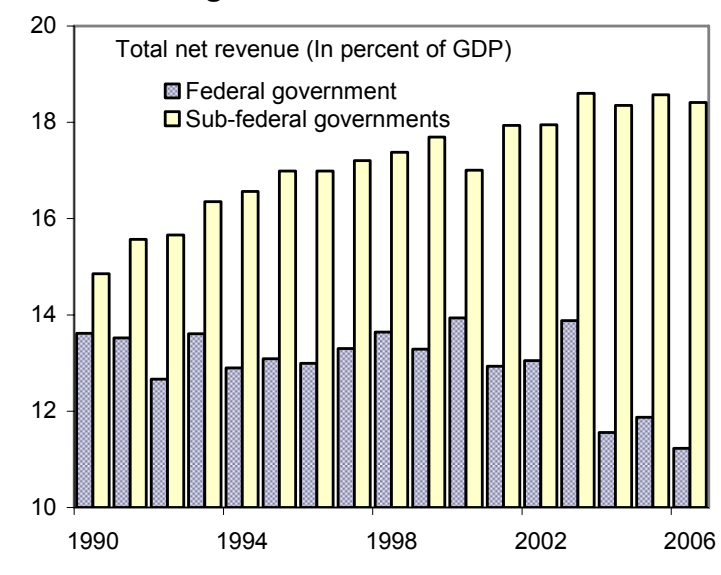


surpluses for seven years in a row has established fiscal credibility, but interest savings have been used for spending and tax reductions (Table 5). The authorities felt that this strategy had been necessary to secure the recent good performance of the economy. Similarly, while the labor market reforms of the Generation Pact represent a breakthrough in awareness, they will not significantly lift employment rates above demographic trends. All agree with the need for further reforms, but the authorities anticipate a lengthy process of consensus-building and gradual action.

17. Addressing the projected rise in aging-related costs requires a mix of fiscal adjustment, growth-enhancing policies, and entitlement reforms (Box 3). Without these reforms or with only the fiscal adjustment as envisaged in the 2006 Stability Program Update, public debt dynamics are unsustainable. Indeed, aging-related expenditure is projected to increase by 5.8 percent of GDP by 2050, even with the employment rate rising by 7.5 percentage points.

\section{A. Fiscal Policy and Institutions}

\section{After being strongly procyclical in $\mathbf{2 0 0 6}$, fiscal policy will tighten in $\mathbf{2 0 0 7}$,} arresting the trend decline in the primary surplus. With higher-than-expected growth and substantial one-off measures, balancing the budget in 2006 represents a structural weakening by about 1 percent of GDP. Conversely, the 2007 budget aims for a structural improvement of 0.6 percent of GDP, and recourse to one-off measures is being reduced. However, with revenue projections somewhat optimistic, the staff sees a remaining gap of about 0.3 percent of GDP (Text Table), which it urged the authorities to close with durable measures. The

Belgium: General Government Fiscal Indicators, 2000-07

(In percent of GDP, unless otherwise indicated)

\begin{tabular}{|c|c|c|c|c|c|c|c|c|}
\hline & \multirow[b]{2}{*}{2000} & \multirow[b]{2}{*}{2001} & \multirow[b]{2}{*}{2002} & \multirow[b]{2}{*}{2003} & \multirow[b]{2}{*}{2004} & \multirow[b]{2}{*}{2005} & \multicolumn{2}{|c|}{ Projections } \\
\hline & & & & & & & 2006 & 2007 \\
\hline Balance excluding Eurostat adjustment 1/ & 0.1 & 0.6 & 0.0 & 0.0 & 0.0 & 0.1 & 0.0 & 0.0 \\
\hline Balance including Eurostat adjustment 2/ & 0.1 & 0.6 & 0.0 & 0.0 & 0.0 & -2.3 & 0.0 & 0.0 \\
\hline Cyclically-adjusted balance & -1.0 & 0.0 & -0.2 & 0.4 & 0.1 & -1.8 & 0.1 & 0.0 \\
\hline Nonstructural measures (-) & -0.2 & 0.4 & 0.2 & 1.2 & 0.8 & -2.0 & 0.7 & 0.4 \\
\hline Structural balance & -0.8 & -0.4 & -0.5 & -0.8 & -0.7 & 0.2 & -0.7 & -0.4 \\
\hline Interest payments (+) & 6.6 & 6.5 & 5.7 & 5.3 & 4.7 & 4.3 & 4.1 & 3.9 \\
\hline Structural primary balance & 5.8 & 6.0 & 5.2 & 4.5 & 4.0 & 4.5 & 3.5 & 3.5 \\
\hline Change in structural balance & -0.8 & 0.3 & 0.0 & -0.4 & 0.1 & 0.9 & -0.9 & 0.3 \\
\hline Change in structural primary balance & -0.2 & 0.2 & -0.8 & -0.8 & -0.5 & 0.5 & -1.0 & 0.0 \\
\hline \multicolumn{9}{|l|}{ Memorandum items: } \\
\hline Real primary spending growth (in percent) $1 /$ & 1.8 & 1.2 & 5.0 & 5.0 & 0.0 & 3.3 & 1.8 & 2.1 \\
\hline Tax revenue & 44.3 & 44.4 & 44.7 & 44.2 & 44.5 & 44.8 & 44.2 & 44.0 \\
\hline Public debt 3/ & 103.3 & 106.4 & 103.2 & 98.6 & 94.4 & 93.2 & 89.0 & 85.6 \\
\hline
\end{tabular}

Sources: National Bank of Belgium; and IMF staff.

1/ Excludes the effect of the restructuring of the national railway company in 2005.

2/ According to Eurostat, the debt transfer of the national railway company to the Railway Infrastructure Fund should be accounted as expenditure in 2005.

3/ The 2005 public debt figure is consistent with Eurostat's treatment of the national railway company debt transfer. According to the authorities, the public debt figure should be 91.5 percent of GDP. 


\section{Box 3. Aging and Fiscal Sustainability}

Between 2005 and 2050, total net aging costs are expected to rise by 5.8 percent of GDP. To deal with this issue, the authorities plan to build up fiscal surpluses and implement growth and productivity-enhancing reforms.

Four scenarios detailed below illustrate that (i) without growthenhancing structural reforms, fiscal sustainability cannot be secured; (ii) the reform scenario implied in the analysis of the Study Committee on Aging (SCA) combined with the fiscal policy assumptions in the 2006 Stability Program Update does not ensure a stable steady-state debt; and (iii) achieving steady-state debt through additional structural reforms only is likely to be a tall order. In particular, annual labor productivity growth would need to be 0.4 percent permanently higher than in the baseline macroeconomic scenario. However, further direct pension and health care reforms that yield a decline in aging costs of 0.5 percent of GDP by 2030 would also do the job.

Staff baseline. Annual labor productivity growth is assumed to average 1.5 percent during 2005-50, in line with the average productivity growth over the past two decades. Employment is expected to remain constant, reflecting an increase in the employment rate by about 5 percentage points, which is feasible on the basis of cohort effects.

Balanced budgets are assumed over the medium term, allowing a reduction

Public Debt Scenarios (Percent of GDP)

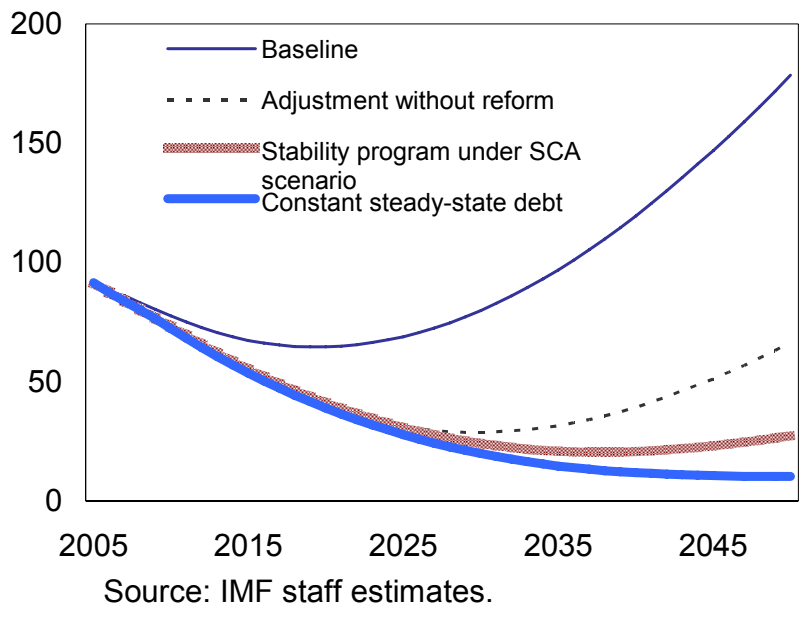

Belgium: Macroeconomic Assumptions

2005-11 2011-30 2005-30 2005-50

Baseline and adjustment without reform

$\begin{array}{lllll}\text { Real GDP growth 1/ } & 2.0 & 1.5 & 1.6 & 1.5 \\ \text { Employment growth 1/ } & 0.6 & 0.0 & 0.1 & 0.0 \\ \text { Labor productivity growth 1/ } & 1.4 & 1.5 & 1.5 & 1.5 \\ \text { Employment ratio 2/ } & 1.6 & 3.0 & 4.6 & 5.0 \\ \text { Participation ratio 2/ } & 1.1 & 3.2 & 4.3 & 4.8\end{array}$

Study Committee on Aging (deviation from baseline)

\begin{tabular}{lllll} 
Real GDP growth 1/ & 0.1 & 0.3 & 0.3 & 0.3 \\
Employment growth 1/ & 0.1 & 0.2 & 0.2 & 0.1 \\
Labor productivity growth 1/ & 0.0 & 0.2 & 0.1 & 0.2 \\
Employment ratio 2/ & 0.6 & 2.1 & 2.7 & 2.4 \\
Participation ratio 2/ & 0.6 & 0.4 & 1.0 & 0.7 \\
\multicolumn{5}{l}{ Constant steady-state debt (deviation from baseline) } \\
Real GDP growth 1/ & 0.2 & 0.5 & 0.4 & 0.5 \\
Employment growth 1/ & 0.1 & 0.2 & 0.2 & 0.1 \\
Labor productivity growth 1/ & 0.0 & 0.4 & 0.3 & 0.4 \\
Employment ratio 2/ & 0.6 & 2.1 & 2.7 & 2.4 \\
Participation ratio 2/ & 0.6 & 0.4 & 1.0 & 0.7
\end{tabular}

Sources: Committee on Aging's 2006 Report; and IMF staff. 1/ Period average, percent change. 2/ Change in percentage points. of the public debt-to-GDP ratio to 65 percent, but rising costs of aging are not offset in the long run. Under this scenario, the public debt-to-GDP ratio would increase without bound. 


\section{Box 3. Aging and Fiscal Sustainability (concluded)}

Adjustment without reform. In addition to the baseline, upfront fiscal adjustment is implemented to reach the staff-recommended surplus of 1.8 percent of GDP by 2012 and then sustain it through 2018 . This would significantly reduce the debt ratio initially to a low of 30 percent of GDP by 2028, but thereafter, rising costs of aging begin to dominate. Indeed, the interest savings obtained in this strategy are insufficient to cover the costs of aging, and indebtedness would again rise without bound, though later and at a slower pace than in the baseline.

SCA scenario. Annual labor productivity growth is assumed to be 1.7 percent, consistent with TFP growth of 1.1 percent (which corresponds to the estimate of the EU15's TFP growth during 1970-2004). Further, capital deepening of 0.6 percent of GDP is assumed, and structural reforms are expected to boost the employment rate by 2.5 percentage points above the baseline, which allows employment to grow by 0.1 percent per year during the projection period. Fiscal adjustment follows the path outlined in the 2006 Stability Program Update to reach a surplus of 1.5 percent by 2013. This scenario comes close to achieving fiscal sustainability and brings the public debt-toGDP ratio down to about 20 percent of GDP by 2030 . However, aging costs continue to rise appreciably until 2050, by which time the public debt ratio will have resumed an upward trend.

Constant steady-state debt. This purist scenario derives the reforms needed to ensure that the public debt ratio becomes constant when the dependency ratio stabilizes in 2050 . This would require additional structural reforms to yield an extra $1 / 4$ percent of labor productivity growth per year.

In sum, while the parameters of these scenarios are subject to considerable uncertainty, the values retained by the SCA for some of them (notably labor productivity growth and the timing and impact of structural reforms) seem to be on the sanguine side. In addition, given the already high capital-labor ratio, assuming further capital deepening may not be justified. However, small entitlement reforms to reduce the projected increase in the cost of aging would insure against the risk of other structural reforms yielding insufficient benefits.

authorities disputed this assessment while emphasizing their intention to take any necessary additional measures in the context of the quarterly reviews of budget implementation. General government spending is set to grow marginally slower than GDP, while federal government expenditure is much tighter. Conversely, regional authorities, which have little or no debt and an increasing share of revenue, are set to ramp up spending.

\section{The authorities remain committed to prefunding a significant share of aging-}

related costs. The budget surplus is expected to rise gradually to 1.1 percent of GDP 
in 2011. However, the HCF is preparing new long-term projections that suggest that more effort is needed to ensure sustainability and that complete prefinancing is not realistic. The staff therefore argued for building up the surplus to 1.5 percent of GDP by 2011 and further beyond this date, in evenly-paced annual adjustments; implementing some additional pension reforms; and more vigorously pursuing productivity-enhancing reforms (Table 6). This approach takes into account the Belgian society's strong preference for intergenerational fairness in the face of an onset of aging earlier than in many other countries and a realistic estimate of the contribution of other structural reforms to the resolution of the aging problem. The authorities accepted that medium-term fiscal consolidation would have to be more ambitious than envisaged in the 2005 stability program update but felt that they could spread the adjustment further in time.

\section{Without a specific medium-term strategy to reduce expenditure, backed by} a solid consensus, the planned fiscal adjustment may fail to materialize. Year-to-year achievement of nominal targets has been relying on one-off operations to balance the books, diverting attention from reforms that would yield durable and increasing savings (e.g., the streamlining of operations of different levels of government, an increase in efficiency of the civil service utilizing natural attrition, a reduction in subsidies, elimination of early retirement schemes, and instauration of a time limit on unemployment benefits). The authorities noted that the complete spending autonomy of the regions constituted an obstacle. They were receptive to a more universal move to performance-based budgeting to improve the overall efficiency of the public sector.

\section{Faster progress in curbing spending and reforming labor markets would render} recent tax reforms more effective in promoting employment and investment. Cuts in social security contributions have only recently begun to lower labor costs, mainly in sectors under strong competitive pressure. Shifts from income taxes to indirect taxes have been increasing incentives to work and will benefit the environment, but - through the universal practice of wage indexation - have been pushing up wage demands and the public wage bill, thus slowing job creation. The introduction of an allowance for corporate equity (ACE) will diminish distortions ${ }^{8}$ but had to be accompanied by revenue-increasing measures to offset its budgetary impact and will promote investment more in capital- than in labor-intensive sectors. The authorities emphasized that the ACE would positively impact employment as well, though it might lead to short-term revenue loss. Noting that effective corporate taxes were already among the lowest in the world and that production was already very capital intensive, the staff saw merit in a more determined reduction of the tax wedge on labor-one of the highest by international standards.

22. The revision of fiscal federalism arrangements has become a priority. Imbalances embedded in these arrangements are widening rapidly. Specifically, regional entities are

\footnotetext{
${ }^{8}$ The ACE is estimated to lower the effective corporate tax rate by 4 percentage points.
} 
experiencing rapid revenue growth due to increased transfers stemming from the parameters built into these arrangements, but they have no real incentive to save these increases. In this context, the authorities welcomed the staff's call for an urgent revision of the arrangements and for increased accountability and better coordination of fiscal and other economic policies among all levels of government. Choices on this sensitive issue are ultimately political. To inform the debate, the staff saw a need for improving the availability of budget information at the regional level.

\section{Against this background, a further strengthening of the fiscal framework and}

fiscal institutions will be essential. While recognizing the merits of an expenditure-based framework, the authorities felt confident that setting medium-term tax policy and nominal budget objectives would suffice to control spending, while an expenditure framework would be cumbersome to coordinate. They agreed that a stronger internal stability pact among levels of government was necessary and that the HCF, which had resumed its activities after an inopportune lapse, would need to step up its role. In particular, the staff emphasized the HCF's mandate to assess compliance with stability programs and intergovernmental agreements on budget targets, which could usefully be complemented by an ex ante evaluation of the budgets of the various layers of government.

\section{B. Employment Creation and Productivity Growth}

\section{Low participation and high structural} unemployment signal labor market rigidities. While the upward trend in employment rates is set to continue, it will contribute only two thirds of the increase needed to validate the authorities' fiscal sustainability scenario. The measures of the Generation Pact are likely to raise the employment rate by a further 1 percentage point out of the required $2 \frac{1}{2}$ percentage points. Unemployment continues to be structurally very high for the low skilled and the young, with very sharp regional differences (Figure 15).

\section{With recently agreed-upon labor market}

Figure 15. Regional unemployment rates diverge significantly.

(2005, in percent of labor force, Eurostat definition)

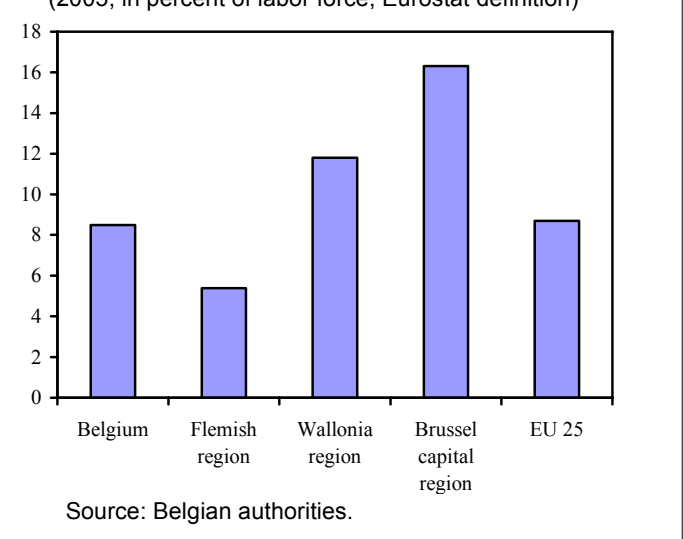
reforms still being implemented, the authorities judged it premature to consider new measures. Emphasis is being placed on activation and training policies, while the recent cut in marginal taxes on the high skilled and efforts to promote research and development are expected to have positive spillovers. The authorities agreed that the tax wedge on labor should be further reduced and education and training improved, but saw no consensus for curbing the level and duration of out-of-work benefits and fully phasing out early retirement schemes.

26. The authorities doubted that an overhaul of the central wage-bargaining framework would have appreciable benefits. Indeed, there was no support from labor 
unions and employers for a fundamental change in the framework. They argued that it had contained wage pressures well over the medium term and that opening it up would likely lead to wage drift, especially as profitability was high and the labor market relatively tight. Accordingly, social partners had agreed to correct the recent slight overrun of the wage norm, but labor unions called for the correction to be spread over four rather than two years. The staff observed that the central bargaining framework, based on the so-called "competitiveness law," did not take into account productivity developments and had not prevented loss of competitiveness, especially in the manufacturing sector (Box 4). Indexation remained an anachronistic feature of the framework, though several sectors had put mechanisms in place to mitigate its effects. Pointing to significant differences in the level of wages across sectors, enterprises, and regions, the authorities disputed the staff's claimbased on the observation that wage differentials had hardly budged over the past decadethat the framework hampered wage differentiation.

27. Social partners nonetheless recognized that the bargaining framework had to be made more conducive to job creation. The staff suggested to keep wage increases below the projected increase for trading partners as long as employment rates had not caught up. The Central Economic Council, in its regular report on establishing the margin for wage negotiation, had begun to report a broader battery of economic performance indicators to help influence the debate.

\section{Disparities in regional labor market performance point to the need to} differentiate but also to coordinate federal and regional labor market policies (Table 7). Regions faced with low employment rates of older workers and a more rapidly aging population should focus on keeping older workers in the labor force, but are unlikely to be successful if early retirement schemes are not phased out. Coexistence of job shortages in some regions with high rates of vacancies in others calls for strengthening mobility and cross-regional training programs. Resolving high youth and female unemployment rates in some regions will require adjusting the level and the tax treatment of benefits, set at the federal level, in order to lower reservation wages.

\section{Ongoing product market reforms and deregulation are raising economic}

efficiency. The administrative burden on businesses and households has been reduced, improving an area that scored poorly according to the OECD. Liberalization of the energy sector has led to lower gas and electricity prices for wholesale customers, but competition in the retail market needs to be unleashed. Complete privatization of telecommunications and deeper reforms of railway and postal services would increase efficiency but are not on the near-term agenda. While the opening-up of the services sector to international competition is set to take place in line with the EU directive, agreement has been reached to selectively allow entry of 113 professions that are in short supply on the domestic labor market. Following consultation with stakeholders, retail shop opening hours are set to be liberalized. 


\section{Box 4. Wage Formation and External Competitiveness ${ }^{1}$}

Belgium's centralized wage-bargaining framework is based on a so-called "competitiveness law." It was introduced in 1996 to promote employment and preserve external competitiveness vis-à-vis France, Germany, and the Netherlands. The law requires that the growth of nominal hourly labor costs for Belgian enterprises in a period of two years does not exceed a "wage norm": the weighted average of the estimated increases in labor costs in these three countries. In addition, wages are to be indexed.

Although the norm has been largely adhered to, competitiveness has eroded, especially in the manufacturing sector (Table and Figure). This is mainly because real wage growth has not been linked to relative productivity developments between Belgium and the three neighboring countries. Indeed, while labor cost has not been out of line, productivity growth in the manufacturing sector has been lagging behind. Moreover, competitiveness should be considered against a broader set of trading partners. Overall, eroding competitiveness has not yet become a serious problem, as demonstrated by the stable export market shares in nominal terms both globally and in key trading partner countries (although export shares in volume term have declined), but it will be if current trends continue.

While decentralization of the wage-bargaining framework may not be politically feasible in the short term, some changes to the framework are necessary to prevent further losses in competitiveness. For the 2007-08 wage round, "all-in" agreements should be encouraged to minimize high wage increases due to inflation surprises, and tax cuts should not be used to allow higher take-home pay, but should lead unambiguously to lower labor costs. The law that past overruns of the wage norm should be corrected in the subsequent wage agreements needs to be enforced. In the longer run, the framework needs to be changed to take into account productivity developments in Belgium and neighboring countries as well as productivity differentials at the sectoral and enterprise levels.

Belgium: Unit Labor Costs in the Private Sector, 1997-2006

(Percentage change from previous year, adjusted for seasonal and calendar effects)

\begin{tabular}{|c|c|c|c|c|c|c|}
\hline & $1997-98$ & 2000 & 2001-02 & 2003-04 & $2005-06$ & 1997-2006 \\
\hline Gross wages per hour worked & 2.8 & 6.1 & 7.1 & 3.7 & 4.5 & 24.2 \\
\hline Collectively agreed wages $1 /$ & 3.7 & 4.4 & 7.1 & 4.2 & 5.0 & 24.4 \\
\hline Agreed real wage increases & 1.0 & 1.8 & 2.2 & 1.4 & 1.0 & 7.4 \\
\hline Indexations & 2.7 & 2.6 & 4.9 & 2.8 & 4.0 & 17.0 \\
\hline Wage drift 2/ & -0.9 & 1.7 & 0.0 & -0.5 & -0.5 & -0.2 \\
\hline Employers' social security contributions $3 /$ & 1.1 & -1.3 & 1.1 & -0.1 & -0.3 & 0.5 \\
\hline $\begin{array}{l}\text { Labor costs per hour worked } \\
\text { In France, Germany, and the Netherlands }\end{array}$ & $\begin{array}{l}3.9 \\
3.5\end{array}$ & $\begin{array}{l}4.8 \\
5.4\end{array}$ & $\begin{array}{l}8.2 \\
6.7\end{array}$ & $\begin{array}{l}3.6 \\
4.5\end{array}$ & $\begin{array}{l}4.2 \\
3.5\end{array}$ & $\begin{array}{l}24.7 \\
23.6\end{array}$ \\
\hline Labor productivity 4 / & 3.4 & 3.1 & 2.7 & 3.2 & 2.6 & 15.0 \\
\hline Unit labor costs & 0.5 & 1.7 & 5.5 & 0.4 & 1.6 & 9.7 \\
\hline
\end{tabular}

Source: Belgian authorities.

1/ Wage increases fixed by Interprofessional Wage Agreements (IPA).

2/ Resulting from increases and bonuses granted by firms, as well as from changes in employment structures.

$3 /$ Contribution to changes in labor costs.

4/ Value-added at constant prices per hour worked by employees and self-employed persons.

${ }^{1}$ See Selected Issues Chapter "Wage Formation and Competitiveness in Belgium." 


\section{Box 4. Wage Formation and External Competitiveness (concluded)}

Belgium and Three Neighboring Countries: Unit Labor Costs,1995-2005
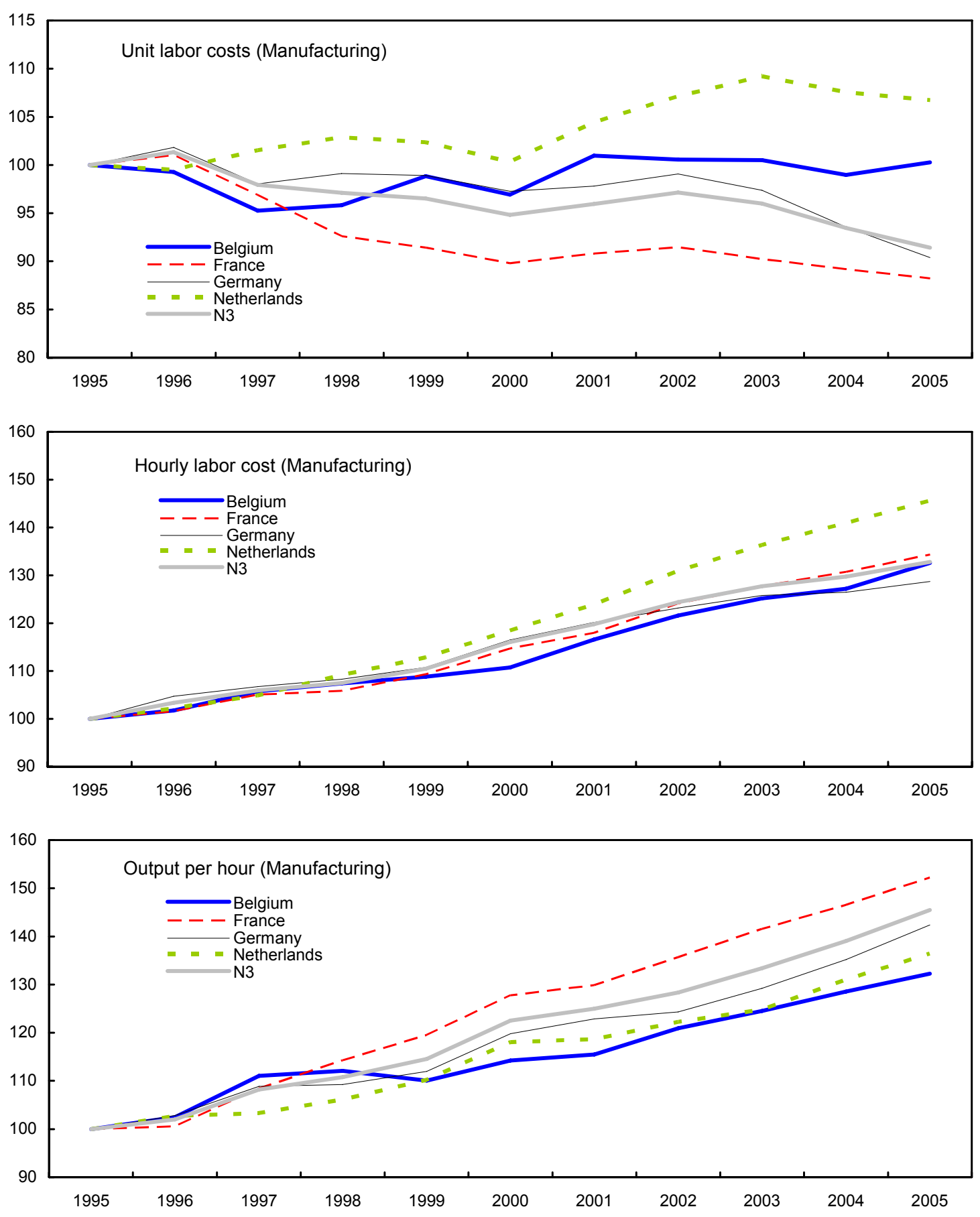

Source: U.S. Department of Labor, Bureau of Labor Statistics. 


\section{Staff Appraisal}

30. Supported by sound economic policies, the economy has been performing well, and the financial sector has gained further resilience, but policies will need to be strengthened to meet the long-run challenges posed by population aging and globalization. Achieving nominal budget targets for seven years running has firmly established the credibility of fiscal policy, though it has been associated with a trend decline in the primary budget surplus. Addressing aging and globalization now requires building up budget surpluses, broadening labor market reforms, and further improving education and the functioning of product markets. Policy actions need to be taken early on to preserve adequate pensions and high quality health care in the long run. Hence, a decisive strengthening and improved coordination of policies across all levels of government should be a priority of the next government.

31. Economic activity is expected to ease to a robust pace. GDP growth is projected to slow to 2.2 percent in 2007, as rising interest rates dampen demand, the external environment softens, and the fiscal policy stance turns from strongly procyclical to slightly restrictive. Uncertainties surrounding this outlook are associated with house prices, external demand, and the euro. While the real effective exchange rate is not overvalued on fundamentals, the recent erosion of competitiveness has to be halted, through both wage moderation and productivity-enhancing structural reforms. Cuts in social security contributions to help lower labor costs should be used sparingly and not to obtain agreements that include higher takehome pay.

32. The financial system is strong and resilient, and there are no stability concerns, but supervisors will have to adapt to its changing systemic risk profile. Major strides have been made in improving the already high quality of supervision, in line with the 2005 FSAP recommendations. Ongoing stress tests could be usefully refined, and the recently conducted liquidity stress tests should be turned into a recurrent exercise in view of likely changes in global liquidity conditions. Fuller advantage now should be taken of the synergy between the NBB and the CBFA. With bank-insurance groups rapidly expanding in nontraditional areas and abroad, supervisors will need to focus more on these issues. Concurrently, the increasing international dimension of Belgium's financial system underscores the importance of strengthening the information exchange and international cooperation among supervisors.

33. Dealing with aging and globalization requires a multi-pronged approach, which is partly under way and broadly recognized in principle but needs to be fully implemented in practice:

- Intergenerational fairness demands significant prefunding of the rise in aging costs, for which fiscal consolidation will have to become more ambitious than envisaged. Fiscal surpluses should be raised to about 1.8 percent of GDP by 2012, in evenly 
paced annual adjustments, based on a strategy of primary expenditure restraint across all levels of government.

- $\quad$ Further reforms of the pension system are important: early retirement schemes should be fully phased out and pension discounts made actuarially fair. Building on recent progress, the growth of health care spending should be durably reduced.

- Employment rates are expected to rise significantly due to demographics and the implementation of the Generation Pact, but additional reforms of labor market institutions will be key.

- Finally, welcome reforms in product markets, reductions in the administrative burden, and policies to promote innovation are creating growth opportunities. To benefit fully, obstacles to competition in the services sector need to be removed.

34. The structural adjustment targeted in the 2007 budget is consistent with the strategy to deal with aging, but additional measures are likely to be required to reach budget objectives. On the positive side, one-off measures are being reduced, a trend that should be locked in. However, revenue projections seem optimistic, and primary spending is set to grow only marginally slower than GDP, thus delaying progress in consolidation. Additional measures taken to close the gap should be of a durable nature to support the requisite rise in surpluses.

\section{Successful consolidation calls for a revision of fiscal federalism arrangements} and a further strengthening of fiscal institutions. Imbalances between regional and federal entities are set to widen, with regions facing little incentive to save the increase in revenues they are experiencing. In revising the arrangements, any further devolution should be accompanied by strengthened accountability and stronger coordination among federal and sub-federal entities of both budgetary and other economic policies. In this context, the resumption of the activities of the HCF is timely and welcome, and a further strengthening of the internal stability pact is warranted.

\section{Building on the initial steps taken with the Generation Pact, additional labor} market reforms will be essential to lift employment rates to levels prevailing in neighboring countries and to achieve Lisbon objectives. The sharpened focus on activation policies is highly appropriate, but to be effective, labor market policies will need to be streamlined and coordinated across regions. In a balanced package and mindful of the implications for the budget, the tax wedge on labor should be further reduced and the generosity of out-of-work benefits lowered. The duration of unemployment benefits will have to be effectively limited and training efforts bolstered. Over the medium term, the wage-bargaining framework needs to be made more conducive to job creation. In particular, it will be crucial to forego the practice of indexation and to take better account of productivity differentials between regions, sectors, and enterprises in setting wages.

37. It is proposed that the next Article IV consultation be held on the standard 12-month cycle. 
Table 1. Belgium: Basic Data, 2001-07

Demographic and other data:

Population (2005)
GDP per capita (2005)
Social indicators (2003)
Life expectancy at birth
Male
Female
Infant mortality rate
Population per physician (1995)
Population per sq. km. (1995)

Private consumption

Public consumption

Gross capital formation

Exports of goods and services

Imports of goods and services

GDP
10.5 million

$\$ 35,712$

75.1

81.1

5 per 1,000 live births

437

335

\begin{tabular}{|c|c|c|c|c|c|c|}
\hline \multicolumn{2}{|c|}{1995} & \multicolumn{3}{|c|}{2005} & & \\
\hline $\begin{array}{l}\text { Billions } \\
\text { of Euros }\end{array}$ & $\begin{array}{l}\text { Percent } \\
\text { of GDP }\end{array}$ & & $\begin{array}{l}\text { Billions } \\
\text { of Euros }\end{array}$ & $\begin{array}{l}\text { Percent } \\
\text { of GDP }\end{array}$ & & \\
\hline 109.6 & 54.2 & & 158.8 & 53.1 & & \\
\hline 43.1 & 21.3 & & 68.6 & 22.9 & & \\
\hline 40.3 & 19.9 & & 59.4 & 19.9 & & \\
\hline 140.4 & 69.4 & & 258.3 & 86.3 & & \\
\hline 131.3 & 64.9 & & 250.0 & 83.5 & & \\
\hline \multirow[t]{2}{*}{202.3} & 100.0 & & 299.2 & 100.0 & & \\
\hline & & & & & Est. & Proj. \\
\hline 2001 & 2002 & 2003 & 2004 & 2005 & 2006 & 2007 \\
\hline
\end{tabular}

(Changes in percent)

\section{National accounts}

Demand and output (volume)

$$
\text { GDP }
$$

Private consumption

Public consumption

Gross fixed investment

Of which: enterprise investment

Excluding exceptional operations

Stockbuilding $1 /$

Total domestic demand

Exports of goods and nonfactor services

Imports of goods and nonfactor services

Foreign balance $1 /$

Output gap (in percent of potential GDP)

\section{Labor market}

Labor force (national definition)

Employment (national definition)

EU harmonized unemployment rate 2/

NAIRU 2/

$\begin{array}{rrrrrrr}0.7 & 1.4 & 1.0 & 2.7 & 1.5 & 2.9 & 2.2 \\ 0.8 & 0.7 & 1.0 & 1.6 & 0.9 & 2.3 & 2.0 \\ 2.4 & 2.9 & 2.2 & 1.8 & -0.3 & 1.1 & 1.4 \\ -0.1 & -1.4 & -0.7 & 6.9 & 5.2 & 3.5 & 3.1 \\ 3.0 & -1.9 & -2.3 & 6.6 & 4.8 & 6.1 & 5.5 \\ 1.9 & -1.4 & -2.3 & 2.9 & 5.4 & \ldots & \ldots \\ -0.9 & 0.1 & 0.0 & 0.2 & 0.5 & 0.4 & -0.3 \\ 0.0 & 0.9 & 0.9 & 2.9 & 2.1 & 2.7 & 1.7 \\ 0.8 & 0.8 & 2.9 & 5.8 & 3.2 & 3.5 & 5.6 \\ -0.1 & 0.2 & 2.8 & 6.2 & 4.0 & 3.6 & 5.5 \\ 0.7 & 0.5 & 0.1 & 0.0 & -0.5 & 0.1 & 0.3 \\ 1.2 & 0.5 & -0.6 & -0.1 & -0.8 & -0.1 & 0.0 \\ & & & & & & \\ & & & & & & \\ 1.2 & 0.2 & 1.1 & 1.3 & 1.3 & 0.9 & 0.9 \\ 1.4 & -0.1 & -0.1 & 0.6 & 0.9 & 1.0 & 1.1 \\ 6.6 & 7.5 & 8.2 & 8.4 & 8.4 & 8.3 & 8.1 \\ 8.3 & 7.9 & 7.9 & 7.9 & 7.8 & 7.8 & 7.6 \\ & & & & & & \\ 2.0 & 1.9 & 1.6 & 2.4 & 2.1 & 1.7 & 1.8 \\ -1.0 & 1.6 & -0.4 & -0.2 & -1.0 & -0.3 & 0.1 \\ 2.4 & 1.6 & 1.5 & 1.9 & 2.5 & 2.4 & 1.9 \\ 4.2 & 3.9 & 1.8 & 2.2 & 2.5 & 2.8 & 2.1 \\ -0.7 & 1.6 & 1.1 & 2.1 & 0.5 & 1.6 & 1.1 \\ 4.8 & 2.4 & 0.7 & 0.1 & 2.0 & 1.2 & 1.0\end{array}$

Prices, wages, and incomes

GDP deflator

Terms of trade (goods)

Consumer price index $3 /$

Compensation per employee 4/

Labor productivity 4/

Unit labor costs 4/ 
Table 1. Belgium: Basic Data, 2001-07 (concluded)

\begin{tabular}{|c|c|c|c|c|c|c|c|}
\hline & 2001 & 2002 & 2003 & 2004 & 2005 & $\frac{\text { Est. }}{2006}$ & $\frac{\text { Proj. }}{2007}$ \\
\hline & \multicolumn{7}{|c|}{ (In percent) } \\
\hline \multicolumn{8}{|l|}{ Interest rates (percent) } \\
\hline Money market rate (3 month) 5/ & 4.3 & 3.3 & 2.3 & 2.1 & 2.2 & 3.0 & $\ldots$ \\
\hline \multirow[t]{2}{*}{ Government bond yield } & 5.1 & 5.0 & 4.2 & 4.1 & 3.4 & 3.8 & $\ldots$ \\
\hline & \multicolumn{7}{|c|}{ (In percent of GDP) } \\
\hline \multicolumn{8}{|l|}{ Saving and investment } \\
\hline Private saving & 24.0 & 24.2 & 23.5 & 24.2 & 26.3 & 24.7 & 25.1 \\
\hline Of which: household saving as percent of & & & & & & & \\
\hline disposable household income & 16.4 & 15.8 & 14.4 & 13.2 & 13.2 & 13.4 & 13.4 \\
\hline Growth of real disposable income (in percent) & 2.2 & -0.2 & -0.6 & 0.4 & 1.3 & 2.4 & 1.1 \\
\hline Private investment & 18.6 & 17.6 & 17.2 & 17.7 & 18.1 & 18.6 & 19.2 \\
\hline Private saving surplus & 5.4 & 6.6 & 6.2 & 6.4 & 8.2 & 6.1 & 6.0 \\
\hline Government saving surplus & -1.1 & -1.7 & -1.6 & -1.7 & -4.1 & -1.5 & -1.1 \\
\hline National saving surplus & 4.3 & 4.9 & 4.6 & 4.7 & 4.1 & 4.5 & 4.8 \\
\hline \multicolumn{8}{|l|}{ Public finances, general government } \\
\hline Revenue & 49.6 & 49.8 & 51.1 & 49.3 & 49.9 & 49.0 & 48.7 \\
\hline Expenditure & 49.0 & 49.8 & 51.1 & 49.3 & 52.2 & 49.0 & 48.8 \\
\hline Of which: interest on public debt & 6.5 & 5.7 & 5.3 & 4.7 & 4.4 & 4.1 & 3.9 \\
\hline Fiscal balance $6 / 7 /$ & 0.6 & 0.0 & 0.0 & 0.0 & -2.3 & 0.0 & 0.0 \\
\hline Primary balance 6/ & 7.0 & 5.7 & 5.4 & 4.7 & 2.0 & 4.1 & 3.9 \\
\hline Structural balance $8 /$ & -0.4 & -0.5 & -0.8 & -0.7 & 0.2 & -0.7 & -0.4 \\
\hline Structural primary balance $8 /$ & 6.0 & 5.2 & 4.5 & 4.0 & 4.5 & 3.5 & 3.5 \\
\hline \multirow[t]{2}{*}{ Gross public debt $7 /$} & 106.4 & 103.2 & 98.6 & 94.4 & 93.2 & 89.0 & 85.6 \\
\hline & \multicolumn{7}{|c|}{ (In billions of euros, unless otherwise indicated) } \\
\hline \multicolumn{8}{|l|}{ Balance of payments } \\
\hline Current account balance & 8.8 & 12.4 & 11.4 & 10.2 & 7.4 & 7.5 & 8.7 \\
\hline (In percent of GDP) & 3.4 & 4.6 & 4.1 & 3.5 & 2.5 & 2.4 & 2.7 \\
\hline Trade balance & 6.2 & 10.2 & 9.7 & 7.8 & 4.7 & 3.8 & 4.7 \\
\hline (In percent of GDP) & 2.4 & 3.8 & 3.5 & 2.7 & 1.6 & 1.2 & 1.4 \\
\hline \multicolumn{8}{|l|}{ Exchange rates } \\
\hline Euro per U.S. dollar (January 4, 2007) 9/ & & & & 0.76 & & & \\
\hline Nominal effective rate $(2000=100)$ & 100.5 & 101.6 & 105.7 & 106.8 & 106.9 & 107.2 & $\ldots$ \\
\hline Real effective rate $(2000=100) 10 /$ & 101.6 & 104.8 & 109.4 & 111.8 & 113.8 & 114.8 & $\ldots$ \\
\hline
\end{tabular}

Sources: Data provided by the authorities; and IMF staff estimates and projections.

$1 /$ Contribution to growth.

2/ Percent of the labor force.

3/ Harmonized consumer price index.

4/ Based on national accounts data, economy-wide.

5/ Since 1999, euro rate.

6/ Includes UMTS license revenue of 0.2 percent of GDP in 2001 and proceeds from the transfer of Belgacom's pension fund of 1.9 percent of GDP in 2003.

$7 /$ Includes the effect of the restructuring of the national railway company in 2005 as presented by Eurostat. According to the authorities, the fiscal balance should be 0.1 percent of GDP in 2005 and the public debt 91.5 percent of GDP. Other elements of the accounts, e.g., total expenditure, would also differ.

8/ Excludes UMTS license revenue of 0.2 percent of GDP in 2001 and proceeds from the transfer of Belgacom's pension fund of 1.9 percent of GDP in 2003.

9/ Belgium entered the final stage of EMU on January 1, 1999 at a rate of 40.3399 Belgian francs to the euro. 10/ Based on relative unit labor costs in manufacturing. 
Table 2. Belgium: Indicators of External and Financial Vulnerability, 2000-06

\begin{tabular}{|c|c|c|c|c|c|c|c|}
\hline & 2000 & 2001 & 2002 & 2003 & 2004 & 2005 & 2006 \\
\hline \multicolumn{8}{|l|}{ External Indicators } \\
\hline Exports (annual percentage change, in U.S. dollars) 1/ & -0.8 & -0.4 & 6.3 & 20.6 & 19.4 & 7.0 & 5.7 \\
\hline Imports (annual percentage change, in U.S. dollars) 1/ & 5.3 & -0.6 & 4.2 & 21.2 & 20.2 & 8.4 & 6.1 \\
\hline Terms of trade (annual percentage change) $1 /$ & -1.3 & -1.0 & 1.6 & 1.2 & 0.5 & -0.3 & -0.3 \\
\hline Current account balance (percent of GDP) $1 /$ & 4.0 & 3.4 & 4.6 & 4.1 & 3.5 & 2.5 & 2.4 \\
\hline Inward portfolio investment (percent of GDP) 1/ 2/ & 56.4 & 63.5 & 8.1 & 2.5 & 1.5 & -0.5 & 2.1 \\
\hline Inward foreign direct investment (percent of GDP) 1/ 2/ & 106.6 & 23.7 & 6.5 & 10.8 & 12.1 & 8.7 & 7.3 \\
\hline Official reserves (in billions of U.S. dollars, end-of-period) 3/ & 10.0 & 11.3 & 11.9 & 11.0 & 10.4 & 8.2 & 8.1 \\
\hline Official reserves (in months of imports) & 0.6 & 0.7 & 0.7 & 0.6 & 0.4 & 0.3 & $\ldots$ \\
\hline Exchange rate per U.S. dollar (period average) 4/ 5/ & 1.082 & 1.117 & 1.059 & 0.884 & 0.804 & 0.803 & 0.799 \\
\hline \multicolumn{8}{|l|}{ Market indicators } \\
\hline \multicolumn{8}{|l|}{ Financial markets indicators $5 /$} \\
\hline Public sector debt (Maastricht definition) 1/ & 107.8 & 106.4 & 103.2 & 98.6 & 94.4 & 93.2 & 89.0 \\
\hline 3-month T-bill yield (percent) & 4.0 & 4.2 & 3.2 & 2.2 & 2.0 & 2.1 & 3.1 \\
\hline 3-month T-bill yield (real, percent) & 1.5 & 1.7 & 1.5 & 0.6 & -0.3 & -0.4 & 0.7 \\
\hline Spread of 3-month T-bill over EURIBOR (percentage points) & -0.3 & 0.0 & -0.1 & -0.1 & -0.1 & -0.2 & -0.2 \\
\hline 10 -year government bond yield (percent) & 5.6 & 5.1 & 5.0 & 4.2 & 4.3 & 3.4 & 3.8 \\
\hline 10-year government bond yield (real, percent) & 2.9 & 2.7 & 3.4 & 2.7 & 2.5 & 0.9 & 1.4 \\
\hline Spread of 10 -year government bond rate with Germany & & & & & & & \\
\hline (percentage points) & 0.3 & 0.3 & 0.2 & 0.1 & 0.1 & 0.2 & 0.0 \\
\hline Stock market index (period average) & 2,967 & 2,807 & 2,410 & 1,975 & 2,557 & 3,192 & 3,687 \\
\hline \multicolumn{8}{|l|}{ Credit markets indicators (end-of-period, percentage increase) } \\
\hline Credit to the private sector $6 /$ & 3.5 & 1.4 & 1.5 & 3.0 & 1.7 & 8.7 & 5.8 \\
\hline Bank credit to households $6 /$ & 2.4 & -1.1 & 4.1 & 6.8 & 9.6 & 13.5 & 6.0 \\
\hline Mortgages $6 /$ & 7.7 & 2.7 & 8.0 & 11.8 & 11.8 & 15.9 & 7.0 \\
\hline Bank credit to nonfinancial enterprises $6 /$ & 4.4 & -1.2 & -3.0 & -4.1 & -1.5 & 1.2 & 2.4 \\
\hline Number of credit institutions & 119 & 113 & 111 & 109 & 104 & 104 & 104 \\
\hline \multicolumn{8}{|l|}{ Sensitivity to market risk } \\
\hline Off-balance sheet operations of banks as percent of assets & 269 & 304 & 419 & 448 & 535 & 419 & N.R. (now on balance) \\
\hline Of which: foreign exchange operations & 37 & 35 & 42 & 45 & 44 & 39 & N.R. (now on balance) \\
\hline Of which: interest rate operations & 213 & 248 & 354 & 379 & 474 & 356 & N.R. (now on balance) \\
\hline Other & 19 & 22 & 23 & 24 & 17 & 24 & N.R. (now on balance) \\
\hline Net long position in foreign exchange as a percentage of Tier I capital 6/ & 8 & 7 & 9 & 7 & 5 & 6 & 8 \\
\hline
\end{tabular}

Sources: Data provided by the Belgian authorities; IMF, IFS; and IMF Research Department.

$1 /$ IMF staff projection for 2006.

2/ Data before 2002 cover the definition of the Belgium-Luxembourg Economic Union (BLEU).

3/ 2006, October; reserves and foreign liabilities refer to the Belgian central bank, both before and after EMU.

4/ Belgian francs (BEF) per dollar until 1998, euro per dollar thereafter. The fixed BEF/euro conversion rate is 40.3399 .

5/ Latest data.

6/ Data for 2006 are for official data for period January 2006 to June 2006. Nonannualized growth rates. 


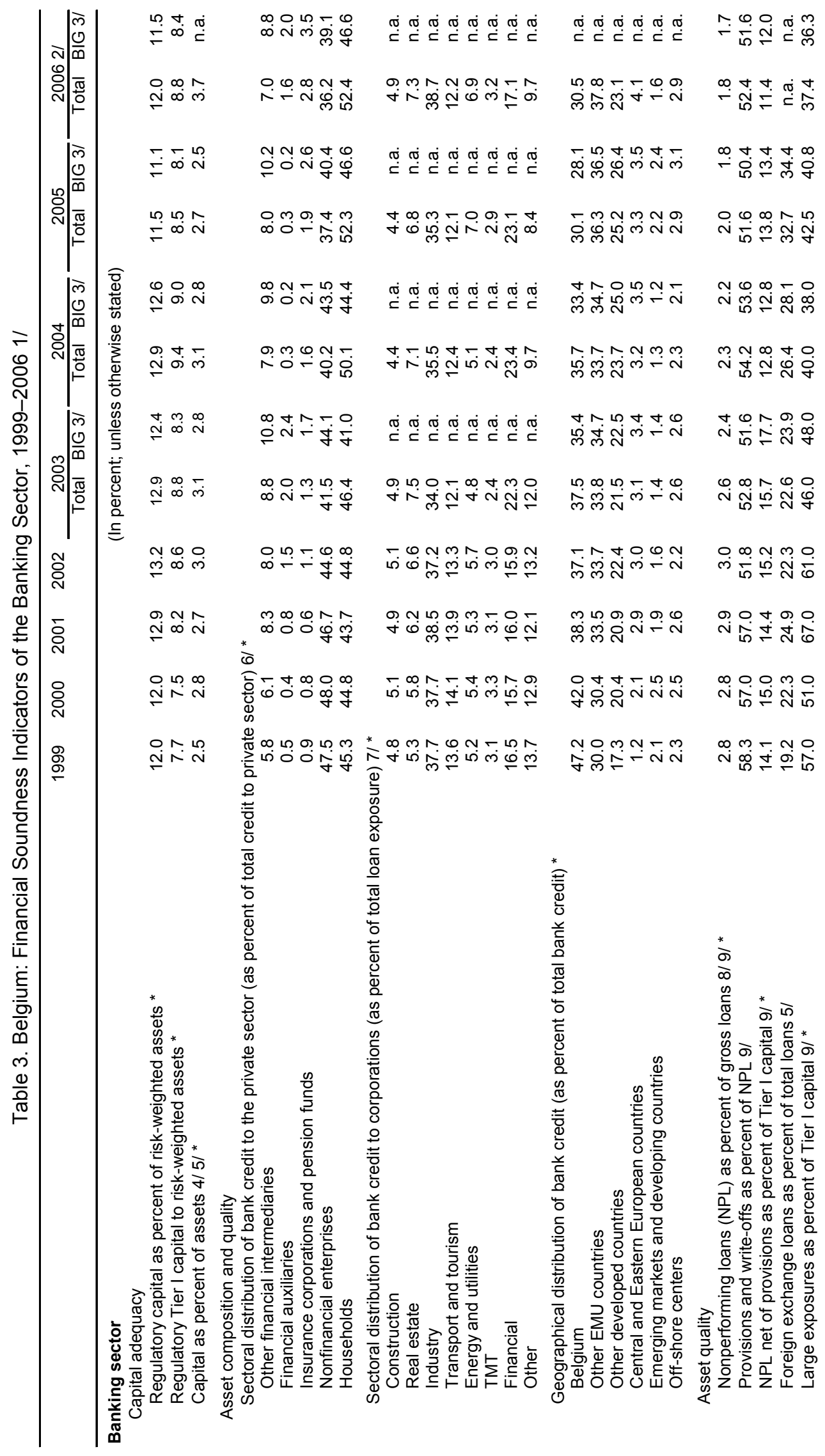




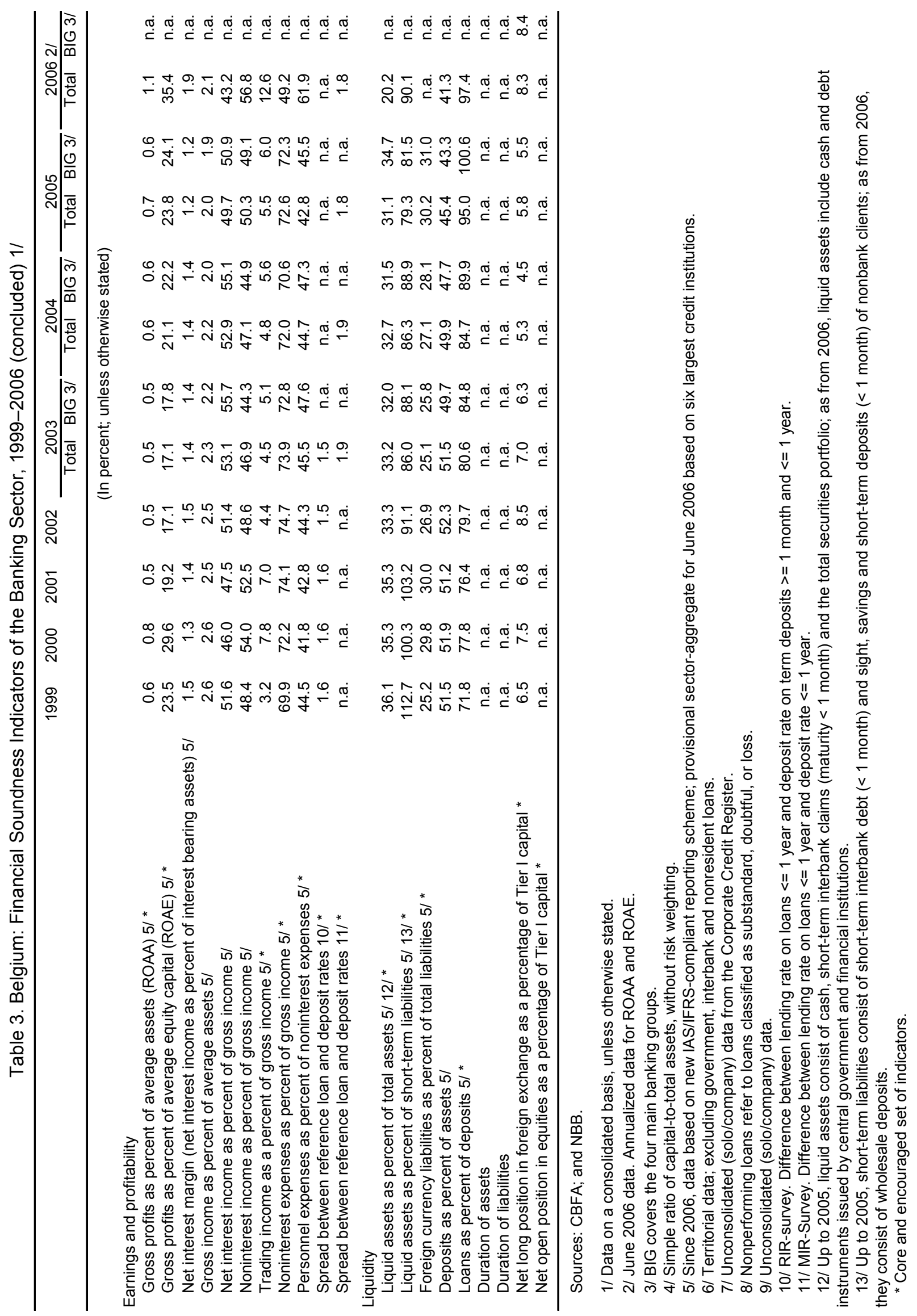


Table 4. Belgium: Financial Soundness Indicators of the Nonbanking Sectors, 1999-2006

\begin{tabular}{|c|c|c|c|c|c|c|c|c|}
\hline & 1999 & 2000 & 2001 & 2002 & 2003 & 2004 & 2005 & $20061 /$ \\
\hline & \multicolumn{8}{|c|}{ (In percent, unless otherwise stated) } \\
\hline \multicolumn{9}{|l|}{ Insurance sector } \\
\hline Coverage ratio $2 /$ & 267.0 & 265.0 & 276.0 & 254.1 & 248.4 & 250.7 & 259.3 & $\ldots$ \\
\hline Profitability (return on average equity) & 26.9 & 21.5 & 12.1 & -10.4 & 7.3 & 18.0 & 23.3 & $\ldots$ \\
\hline Life & 15.3 & 12.4 & 9.4 & -3.0 & 5.6 & 8.4 & 11.7 & $\ldots$ \\
\hline Nonlife & 10.9 & 7.6 & 0.0 & -3.7 & 9.1 & 13.0 & 10.6 & $\ldots$ \\
\hline \multicolumn{9}{|l|}{ Corporate sector $3 /$} \\
\hline Total debt as a percentage of equity * & 95.8 & 88.6 & 83.0 & 79.5 & 78.2 & 70.6 & 62.7 & $\ldots$ \\
\hline Profitability (Return on equity) * & 13.0 & 11.6 & 9.8 & 11.7 & 12.9 & 10.4 & 10.3 & $\ldots$ \\
\hline Debt service coverage $4 /$ * & 180.7 & 179.7 & 113.6 & 176.7 & 195.6 & 182.8 & 280.2 & $\ldots$ \\
\hline Net foreign exchange exposure as a percentage of equity * & n.a. & n.a. & n.a. & n.a. & n.a. & n.a. & n.a. & $\ldots$ \\
\hline Number of applications for protection from creditors * & n.a. & n.a. & n.a. & n.a. & n.a. & n.a. & n.a. & $\ldots$ \\
\hline \multicolumn{9}{|l|}{ Household sector } \\
\hline Debt as a precentage of GDP * & 44.5 & 42.9 & 41.3 & 41.4 & 42.3 & 42.9 & 45.7 & 47.0 \\
\hline Debt service burden as a percentage of total disposable income * & 2.0 & 2.5 & 2.5 & 1.8 & 1.5 & 1.2 & 1.5 & 1.5 \\
\hline Financial savings ratio as a percentage of GDP & 8.0 & 7.3 & 7.6 & 6.0 & 5.5 & 5.0 & 2.8 & 4.7 \\
\hline Savings rate & 17.4 & 15.5 & 16.6 & 15.9 & 14.6 & 13.3 & 13.3 & 13.6 \\
\hline \multicolumn{9}{|l|}{ Real estate sector } \\
\hline \multicolumn{9}{|l|}{ House price inflation $5 /$ * } \\
\hline Houses & 8.7 & 7.1 & 6.4 & 8.2 & 6.6 & 10.3 & 16.2 & 9.0 \\
\hline Apartments & 5.3 & 7.0 & 4.4 & 8.3 & 8.9 & 14.6 & 13.4 & n.a. \\
\hline Mortgage loans as percent of total loans $6 /$ & 21.8 & 20.3 & 20.5 & 22.3 & 27.6 & 27.4 & 26.2 & 32.4 \\
\hline Of which: domestic & 15.3 & 14.2 & 14.1 & 14.9 & 16.1 & 15.9 & 14.9 & 17.2 \\
\hline Of which: domestic households * & 14.6 & 13.8 & 13.3 & 14.2 & 15.6 & 15.5 & 14.5 & 17.0 \\
\hline Of which: commercial real estate * & n.a. & n.a. & n.a. & n.a. & n.a. & n.a. & n.a. & n.a. \\
\hline Variable rate mortgages as percent of total new mortgages & 3.9 & 12.8 & 6.2 & 12.3 & 25.9 & 53.3 & 36.3 & 22.5 \\
\hline
\end{tabular}

Sources: CBFA, NBB, Stadim, UPC.

1/ June 2006 data.

2/ Available solvency marging over required solvency margin.

3/ Data for 2005 based on a sample of already available annual accounts in the Central Balance Sheet Register.

4/ Earnings before interest and tax as a percentage of interest and principal expenses.

5/ Percent change in house price index (1953=100).

6/ Mortgage loans after deduction of deposits related to mortgage loans; consolidated basis (new IAS/IFRS-compliant reporting scheme since 2006).

* Encouraged set of indicators. 
Table 5. Belgium: Operations of the General Government, 1999-2005 1/

(In percent of GDP, unadjusted for working days)

\begin{tabular}{|c|c|c|c|c|c|c|c|}
\hline & 1999 & 2000 & 2001 & 2002 & 2003 & 2004 & 2005 \\
\hline Revenue & 49.5 & 49.2 & 49.6 & 49.8 & 51.1 & 49.5 & 50.0 \\
\hline Tax revenue & 44.7 & 44.4 & 44.4 & 44.7 & 44.2 & 44.7 & 44.9 \\
\hline Direct taxes & 16.9 & 17.1 & 17.3 & 17.1 & 16.7 & 16.8 & 17.1 \\
\hline Personal income tax & 13.5 & 13.6 & 14.0 & 13.9 & 13.6 & 13.4 & 13.4 \\
\hline Company income tax & 3.4 & 3.3 & 3.2 & 3.2 & 3.0 & 3.3 & 3.6 \\
\hline Other direct taxes & 0.1 & 0.1 & 0.1 & 0.1 & 0.1 & 0.1 & 0.1 \\
\hline Indirect taxes & 13.1 & 12.9 & 12.5 & 12.7 & 12.7 & 13.0 & 13.2 \\
\hline Social contributions & 14.3 & 14.0 & 14.2 & 14.4 & 14.3 & 14.1 & 13.9 \\
\hline Other taxes & 0.4 & 0.5 & 0.5 & 0.5 & 0.5 & 0.8 & 0.6 \\
\hline Nontax revenue & 4.8 & 4.7 & 5.2 & 5.1 & 6.9 & 4.8 & 5.1 \\
\hline Expenditure & 50.0 & 49.1 & 49.0 & 49.8 & 51.1 & 49.5 & 52.3 \\
\hline Primary expenditure & 43.2 & 42.5 & 42.6 & 44.1 & 45.8 & 44.8 & 48.0 \\
\hline Current expenditure & 40.0 & 39.4 & 40.2 & 41.6 & 42.7 & 42.5 & 42.9 \\
\hline Wages & 11.8 & 11.5 & 11.7 & 12.2 & 12.3 & 12.1 & 12.1 \\
\hline Operations and maintenance & 3.2 & 3.2 & 3.3 & 3.8 & 3.7 & 3.7 & 3.6 \\
\hline Social transfers & 21.7 & 21.4 & 21.8 & 22.3 & 23.0 & 23.2 & 23.1 \\
\hline Old age & 8.5 & 8.3 & 8.4 & 8.6 & 8.7 & 8.6 & 8.6 \\
\hline Health & 5.5 & 5.6 & 5.8 & 5.7 & 6.1 & 6.3 & 6.3 \\
\hline Unemployment & 1.9 & 1.7 & 1.8 & 2.0 & 2.1 & 2.1 & 2.1 \\
\hline Other social transfer & 5.8 & 5.7 & 5.8 & 6.0 & 6.1 & 6.1 & 6.1 \\
\hline Subsidies to enterprises & 1.3 & 1.3 & 1.3 & 1.2 & 1.4 & 1.2 & 1.7 \\
\hline Other transfers & 2.1 & 2.0 & 2.0 & 2.1 & 2.3 & 2.3 & 2.4 \\
\hline Capital expenditure & 3.2 & 3.1 & 2.4 & 2.5 & 3.1 & 2.3 & 5.1 \\
\hline Interest & 6.8 & 6.6 & 6.5 & 5.7 & 5.3 & 4.7 & 4.3 \\
\hline Overall balance & -0.5 & 0.1 & 0.6 & 0.0 & 0.0 & 0.0 & -2.3 \\
\hline Primary balance & 6.3 & 6.7 & 7.0 & 5.7 & 5.4 & 4.7 & 2.0 \\
\hline \multicolumn{8}{|l|}{ Memorandum items: } \\
\hline Structural balance & 0.0 & -0.8 & -0.4 & -0.5 & -0.8 & -0.7 & 0.2 \\
\hline Central government balance & -0.9 & 0.1 & -0.1 & 0.2 & 0.0 & -0.2 & -0.3 \\
\hline Gross public debt (Maastricht definition) & 113.7 & 107.8 & 106.4 & 103.2 & 98.6 & 94.4 & 93.2 \\
\hline
\end{tabular}

Source: Data provided by the Belgian authorities.

$1 /$ Includes the effect of the restructuring of the national railway company in 2005 as presented by Eurostat. According to the authorities, the overall balance should be 0.1 percent of GDP in 2005 and the public debt 91.5 percent of GDP. Other elements of the accounts, e.g., total expenditure, would also differ. 
Table 6. Belgium: Fiscal Scenarios, 2002-11

(In percent of GDP, unadjusted for working days, unless otherwise indicated)

\begin{tabular}{|c|c|c|c|c|c|c|c|c|c|c|}
\hline & \multirow[b]{2}{*}{2002} & \multirow[b]{2}{*}{2003} & \multirow[b]{2}{*}{2004} & \multirow[b]{2}{*}{2005} & \multirow{2}{*}{$\begin{array}{r}\text { Est. } \\
2006\end{array}$} & \multicolumn{5}{|c|}{ Projection } \\
\hline & & & & & & 2007 & 2008 & 2009 & 2010 & 2011 \\
\hline \multicolumn{11}{|l|}{ Current policies (A) } \\
\hline Revenue & 49.8 & 51.1 & 49.3 & 49.9 & 49.0 & 48.7 & 48.7 & 48.6 & 48.5 & 48.5 \\
\hline Expenditure & 49.8 & 51.1 & 49.3 & 52.2 & 49.0 & 48.8 & 48.7 & 48.6 & 48.5 & 48.4 \\
\hline Primary expenditure & 44.1 & 45.8 & 44.6 & 47.9 & 44.9 & 44.9 & 44.9 & 44.9 & 44.9 & 44.9 \\
\hline Interest payments & 5.7 & 5.3 & 4.7 & 4.3 & 4.1 & 3.9 & 3.8 & 3.7 & 3.6 & 3.4 \\
\hline Balance 1/ & 0.0 & 0.0 & 0.0 & -2.3 & 0.0 & 0.0 & 0.0 & 0.0 & 0.0 & 0.1 \\
\hline Structural balance 2/ & -0.5 & -0.8 & -0.7 & 0.2 & -0.7 & -0.4 & 0.0 & 0.0 & 0.1 & 0.1 \\
\hline Primary balance & 5.7 & 5.4 & 4.7 & 2.0 & 4.1 & 3.9 & 3.8 & 3.7 & 3.6 & 3.5 \\
\hline Structural primary balance 2/ & 5.2 & 4.5 & 4.0 & 4.5 & 3.5 & 3.5 & 3.8 & 3.7 & 3.6 & 3.6 \\
\hline Debt $1 /$ & 103.2 & 98.6 & 94.4 & 93.2 & 89.0 & 85.6 & 82.7 & 79.9 & 77.1 & 74.4 \\
\hline \multicolumn{11}{|l|}{ Memorandum items (in percent): } \\
\hline Real primary expenditure growth $2 /$ & 5.0 & 5.0 & 0.0 & 3.3 & 1.8 & 2.1 & 1.9 & 1.9 & 1.9 & 1.9 \\
\hline Real discretionary spending growth $2 /$ & 6.5 & 5.3 & -3.8 & 4.9 & 1.6 & 1.8 & 1.5 & 1.5 & 1.5 & 1.5 \\
\hline Output gap & 0.5 & -0.6 & -0.1 & -0.8 & -0.1 & 0.0 & 0.0 & 0.0 & 0.0 & 0.0 \\
\hline GDP growth & 1.4 & 1.0 & 2.7 & 1.5 & 2.9 & 2.2 & 1.9 & 1.9 & 1.9 & 1.9 \\
\hline \multicolumn{11}{|c|}{ Government scenario; stability program (B) } \\
\hline Revenue & 49.8 & 51.1 & 49.3 & 49.9 & 49.1 & 48.9 & 48.9 & 48.8 & 48.7 & n.a. \\
\hline Expenditure 2/ & 49.8 & 51.1 & 49.3 & 49.8 & 49.1 & 48.6 & 48.4 & 48.1 & 47.8 & n.a. \\
\hline Primary expenditure $2 /$ & 44.1 & 45.8 & 44.6 & 45.5 & 45.0 & 44.7 & 44.76 & 44.7 & 44.5 & n.a. \\
\hline Interest payments & 5.7 & 5.3 & 4.7 & 4.3 & 4.1 & 3.9 & 3.6 & 3.4 & 3.3 & n.a. \\
\hline Balance & 0.0 & 0.0 & 0.0 & 0.1 & 0.0 & 0.3 & 0.5 & 0.7 & 0.9 & n.a. \\
\hline Structural balance $3 /$ & -0.2 & -0.6 & -0.5 & 0.5 & -0.3 & 0.2 & 0.9 & 1.0 & 1.1 & n.a. \\
\hline Primary balance & 5.7 & 5.4 & 4.7 & 4.4 & 4.1 & 4.2 & 4.1 & 4.1 & 4.2 & n.a. \\
\hline Structural primary balance $3 /$ & 5.5 & 4.7 & 4.2 & 4.8 & 3.8 & 4.1 & 4.5 & 4.4 & 4.3 & n.a. \\
\hline Debt & 103.2 & 98.6 & 94.4 & 91.5 & 87.7 & 83.9 & 80.4 & 76.6 & 72.6 & n.a. \\
\hline \multicolumn{11}{|l|}{ Memorandum items (in percent): } \\
\hline Real primary expenditure growth $2 /$ & 5.0 & 5.0 & 0.0 & 3.3 & 1.8 & 1.7 & 2.0 & 1.8 & 1.8 & n.a. \\
\hline GDP growth & 1.4 & 1.0 & 2.7 & 1.5 & 2.7 & 2.2 & 2.1 & 2.2 & 2.2 & n.a. \\
\hline \multicolumn{11}{|l|}{ Staff-recommended scenario (C) } \\
\hline Revenue & 49.8 & 51.1 & 49.3 & 49.9 & 49.0 & 48.7 & 48.7 & 48.6 & 48.5 & 48.5 \\
\hline Expenditure & 49.8 & 51.1 & 49.3 & 52.2 & 49.0 & 48.5 & 48.1 & 47.7 & 47.3 & 46.9 \\
\hline Primary expenditure & 44.1 & 45.8 & 44.6 & 47.9 & 44.9 & 44.6 & 44.3 & 44.1 & 43.8 & 43.6 \\
\hline Interest payments & 5.7 & 5.3 & 4.7 & 4.3 & 4.1 & 3.9 & 3.8 & 3.6 & 3.5 & 3.3 \\
\hline Balance 1/ & 0.0 & 0.0 & 0.0 & -2.3 & 0.0 & 0.3 & 0.6 & 0.9 & 1.2 & 1.5 \\
\hline Structural balance 2/ & -0.5 & -0.8 & -0.7 & 0.2 & -0.7 & -0.1 & 0.6 & 0.9 & 1.2 & 1.6 \\
\hline Primary balance & 5.7 & 5.4 & 4.7 & 2.0 & 4.1 & 4.2 & 4.3 & 4.5 & 4.7 & 4.6 \\
\hline Structural primary balance $2 /$ & 5.2 & 4.5 & 4.0 & 4.5 & 3.5 & 3.8 & 4.4 & 4.5 & 4.7 & 4.9 \\
\hline Debt $1 /$ & 103.2 & 98.6 & 94.4 & 93.2 & 89.0 & 85.3 & 81.9 & 78.2 & 74.4 & 70.3 \\
\hline \multicolumn{11}{|l|}{ Memorandum items (in percent): } \\
\hline Real primary expenditure growth $2 /$ & 5.0 & 5.0 & 0.0 & 3.3 & 1.8 & 1.4 & 1.4 & 1.4 & 1.4 & 1.4 \\
\hline Real discretionary spending growth $2 /$ & 6.5 & 5.3 & -3.8 & 4.9 & 1.6 & 0.6 & 0.5 & 0.5 & 0.4 & 0.4 \\
\hline Output gap & 0.5 & -0.6 & -0.1 & -0.8 & -0.1 & 0.0 & 0.0 & 0.0 & 0.0 & 0.0 \\
\hline GDP growth & 1.4 & 1.0 & 2.7 & 1.5 & 2.9 & 2.2 & 1.9 & 1.9 & 1.9 & 1.9 \\
\hline
\end{tabular}

Sources: Data provided by the authorities; and IMF staff projections.

$1 /$ Includes the effect of the restructuring of the national railway company in 2005 as presented by Eurostat. According to the authorities, the balance should be 0.1 percent of GDP in 2005 and the public debt 91.5 percent of GDP. Other elements of the accounts, e.g., total expenditure, would also differ.

2/ Excludes the effects of the restructuring of the national railway company from expenditures and the impact of the UMTS auctions and capital transfer related to the Belgacom pension fund takeover from revenues.

$3 /$ Adjusted to exclude the impact of nonstructural measures. 
Table 7. Belgium: Regional Indicators

\begin{tabular}{lrrrr}
\hline & Belgium & Brussels & Flanders & Wallonia 1/ \\
\hline Size (share, in percent) & & & & \\
$\quad$ Population (1/1/06) & 100.0 & 9.7 & 57.8 & 32.5 \\
Gross Value Added (GVA) & & & & \\
$\quad$ In constant prices 2004) & 100.0 & 19.4 & 57.2 & 23.3 \\
$\quad$ Labor income (2003) & 100.0 & 20.5 & 55.7 & 23.7 \\
Performance (in percent) & & & & \\
GVA growth 1999-2004 & 2.0 & 2.3 & 2.1 & 1.6 \\
Employment rate (2005) 2/ & 61.1 & 54.8 & 64.9 & 56.1 \\
$\quad$ Ages 55-64 & 31.8 & 39.8 & 30.7 & 32.3 \\
Unemployment rate (2005) 3/ & 8.5 & 16.3 & 5.4 & 11.8 \\
$\quad$ Female & 9.5 & 16.5 & 6.3 & 13.7 \\
$\quad$ Young (15-24) & 21.5 & 35.0 & 14.2 & 32.0 \\
$\quad$ Older (50-64) & 4.4 & 6.5 & 3.8 & 4.8 \\
Fiscal indicators 4/ & & & & \\
Revenue/GDP & 49.0 & 0.8 & 6.4 & 1.9 \\
Expenditure/GDP & 49.0 & 0.8 & 6.3 & 1.8 \\
Balance/GDP & 0.0 & 0.0 & 0.1 & 0.0 \\
Public debt/GDP & 87.4 & 0.5 & 0.1 & 1.9 \\
Aging Indicators & & & & \\
Dependency ratio 2050 5/ & $\ldots$ & 73.0 & 91.0 & 88.0 \\
Old age dependency ratio 2050 6/ & $\ldots$ & 37.0 & 54.0 & 48.0 \\
\hline
\end{tabular}

Source: Belgian authorities.

1/ Fiscal indicators includes only data for the Walloon region.

2/ Employed population as a share of total population aged 15-64.

3/ ILO definition.

4/ Corresponds to 2006 unless otherwise indicated; in percent of overall GDP.

$5 /(0-19+65+) /(20-64)$.

$6 / 65+/(20-64)$. 


\section{APPENDIX I. BELGIUM: FUND RELATIONS}

(As of November 30, 2006)

Mission: Brussels, November 2-13, 2006. The concluding statement of the mission is publicly available at http://www.imf.org/external/np/ms/2006/111306a.htm.

Staff team: Mr. Everaert (Head), Mr. Luzio, and Ms. Zhou (all EUR) and Mr. Ouanes (MCM).

Country interlocutors: the prime minister, the governor of the central bank, the director of the treasury, and their staffs; the chairman of the "Public Sector Borrowing Requirements" Section of the High Council of Finance; the vice-president and minister of labor of the Flemish region; the minister for economy and work of the Brussels region; the minister for finance and budget of the Brussels region; staff of the cabinet of the prime minister; the Financial Stability Committee; the Finance, Banking, and Insurance Commission; the ministry of finance, the ministry of labor; the ministries of the budget, social affairs and health, and the economy; the cabinets of the regional ministers; the Central Economic Council; the Federal Planning Bureau; and representatives of labor unions, employer organizations, and the financial sector. Mr. Kiekens (Executive Director) or Mr. Rottier (Advisor to the Executive Director) attended the meetings.

Fund relations: The previous Article IV Consultation took place on February 27, 2006. The associated Executive Board's assessment is available at http://www.imf.org/external/np/sec/pn/2006/pn0622.htm and the staff report at http:/www.imf.org/external/pubs/ft/scr/2006/cr0674.pdf. Belgium accepted the obligations under Article VIII and, apart from certain security restrictions, maintains an exchange system free of restrictions.

Data: Belgium subscribes to the Fund's Special Data Dissemination Standard, and comprehensive economic data are available on a timely basis (Appendix II).

I. Membership Status: Joined 12/27/45; Article VIII

II. General Resources Account:

Quota

Fund holdings of currency

Reserve position in Fund

\section{SDR Million}

$4,605.20$

$4,180.05$

425.17
\% Quota

100.00

90.77

9.23 
III. SDR Department:

Net cumulative allocation

Holdings
SDR Million

485.25

261.98
\% Allocation

100.00

53.99

IV. Outstanding Purchases and Loans: None

V. Latest Financial Arrangements: None

VI. Projected Payments to Fund (SDR Million; based on existing use of resources and present holdings of SDRs):

\begin{tabular}{l} 
Forthcoming \\
\hline$\underline{2006} \quad \underline{2007} \quad \underline{2008} \quad \underline{2009} \quad \underline{2010}$
\end{tabular}

Principal

Charges/interest

Total

$\frac{9.05}{9.05} \quad \frac{9.07}{9.07} \quad \underline{9.05} \quad \frac{9.05}{9.05} \quad \frac{9.05}{}$

\section{Exchange Rate Arrangement:}

Until December 31, 1998, Belgium formed a monetary union with Luxembourg in which the Belgian and Luxembourg francs were at par, while also participating in the exchange rate mechanism of the European Monetary System. Belgium entered the final stage of European Economic and Monetary Union on January 1, 1999 at a rate of 40.3399 Belgian francs to the euro.

\section{Article IV Consultations:}

Belgium is on the 12-month cycle; the last consultation was completed on February 27, 2006 (EBM/06/19-1).

IX. Belgium has accepted the obligations under Article VIII, Sections 2(a), 3, and 4 of the Fund's Articles of Agreement, and maintains an exchange system free of restrictions on the making of payments and transfers for current international transactions, except for those imposed for security reasons: (1) vis-à-vis Iraq, the Socialist Peoples' Libyan Arab Jamahiriya, and the Federal Republic of Yugoslavia (Serbia and Montenegro) pursuant to UN Security Council resolutions 661, 883, and 757, respectively. The residual restrictions vis-à-vis the Federal Republic of Yugoslavia (Serbia and Montenegro) relate solely to balances of the former National Bank of Yugoslavia that remain frozen, since they are subject to unresolved legal claims; (2) in accordance with the European Council Regulations set forth in the letter from the National Bank of Belgium dated October 30, 2006, and notified to the Executive Board in accordance with Decision No. 144-(52/51) (November 20, 2006). 


\section{FSAP Participation:}

FSAP Assessment

IMF Country Report

No. $06 / 75$

Summary: The report concluded that Belgium's financial system is resilient and benefits from a number of Belgium-specific features that help stability. These include a traditionally cautious attitude toward risk by banks, large holdings of government securities, extremely low holdings of equity by banks, a stable source of funding benefiting from generous tax incentives, a high standard of banking supervision, and a stable macroeconomic policy framework. Overall, supervision showed a high degree of compliance with international standards. Near-term vulnerability appears low, reflecting the soundness of the dominant banking system, the generally benign financial environment, the strong financial condition of the corporate sector, and the relatively healthy financial position of the household sector. Financial institutions were found to withstand an adverse macroeconomic stress well, helped in part by the beneficial diversification in the bancassurance model.

Notwithstanding the strengths of the Belgian financial sector, a number of issues emerged from the FSAP. The heavy exposure abroad, the open nature of the economy, and the importance of the Euroclear Group globally, make the domestic financial system potentially vulnerable to global economic developments and financial contagion. Risks remain and may increase with a downturn in the business cycle, increased cross-border operations, and deeper links with the global money centers. While the financial position of the insurance industry has improved, serious challenges exist, and the supervisions of the insurance and pension funds need to be strengthened. Looking ahead, the Banking, Finance, and Insurance Commission (CBFA) needs to take fuller advantage of the synergies with the National Bank of Belgium (NBB) and further enhance its effectiveness. Maintaining the soundness of the financial system and safeguarding financial stability would call for, in the short term, actions aimed at (1) addressing identified weaknesses in the supervision of the insurance sector; (2) establishing an effective mechanism for consolidated supervision of the bancassurance groups; (3) devoting adequate resources and capacity to the oversight and supervision of the Euroclear Group/Euroclear Bank; (4) continuing to place emphasis on liquidity management; and (5) further enhancing the existing crisis management arrangements. 


\section{APPENDIX II. BELGIUM: STATISTICAL ISSUES}

Belgium's economic and financial statistics are adequate for surveillance purposes. The National Bank of Belgium (NBB) regularly publishes a full range of economic and financial data and provides calendar dates of main statistical releases. On-line access to these comprehensive databases is facilitated by the NBB's data search engine. Belgium is an SDDS subscriber. Statistics for International Financial Statistics on banking institutions and monetary aggregates are prepared on a monthly basis and are timely.

In compliance with EUROSTAT requirements, Belgium adopted chain-linked national accounts statistics in October 2006 and introduced new data sources. ${ }^{9}$ So far, revisions of national accounts for the period 1995-2005, both annually and quarterly, have been completed, while revisions for the earlier years are still under way. GDP growth based on the chain-linked national accounts data is more or less in line with that based on the old series, although the composition of growth has changed somewhat, especially for 2004 and 2005 (Figure below). Specifically, in 2004, the external sector's negative contribution to growth was revised to a small positive contribution, while the growth contribution from private consumption and investment was stronger than suggested by the old national accounts data. In 2005, however, the growth contribution of private consumption and investment was revised down, while the building up of inventories contributed more to the growth.

Both annual and quarterly national accounts data - published within a lag of three monthsare of good quality, with shortcomings mainly related to export and import deflators, which are based on unit values rather than prices collected directly from exporters and importers. Consequently, Belgian export market shares in values have developed rather differently from their shares in volumes. With the chained-link national accounts data, these discrepancies were reduced somewhat.

General government revenue, expenditure, and balance on an accrual basis (ESA95) are published annually. The NBB publishes monthly data on central government operations. It would be helpful to present these data quarterly on a national accounts basis to facilitate monitoring of public finances.

The overall quality and availability of financial indicators are good, while additional indicators for the insurance sector should be developed. The authorities are providing quarterly updates of financial soundness indicators in a timely manner.

\footnotetext{
${ }^{9}$ Unlike in most other countries, the NBB is responsible for compiling national accounts statistics.
} 
Key publicly accessible websites for macroeconomic data and analysis are:

National Statistical Portal ...............................................www.belgostat.be

National Statistics Institute...............................................www.statbel.fgov.be

Institute for National Accounts .....................................www.inr-icn.fgov.be

National Bank of Belgium.............................................www.nbb.be

Federal Planning Bureau .................................................www.plan.be

Banking, Finance, and Insurance Commission .................www.cbfa.be

High Finance Council .....................................................www.docufin.be

Central Economic Council ..............................................www.ccecrb.fgov.be 
Belgium: National Accounts Revisions, 1996-2005
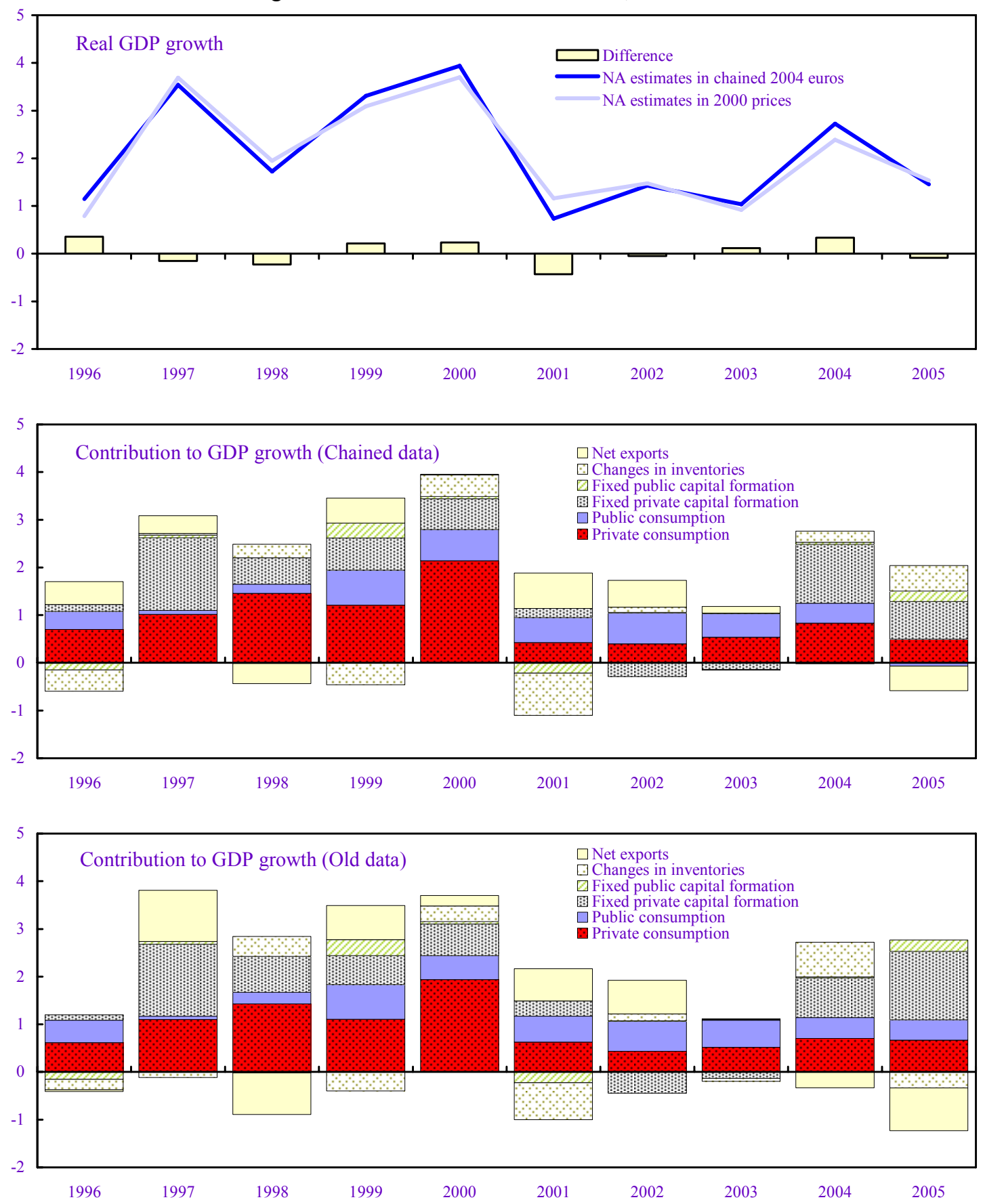

Sources: Belgostat; and IMF staff calculations. 


\section{APPENDIX II. BELGIUM: TABLE OF COMMON INDICATORS REQUIRED FOR SURVEILLANCE}

(As of December 11, 2006)

\begin{tabular}{|c|c|c|c|c|c|}
\hline & $\begin{array}{c}\text { Date of } \\
\text { latest } \\
\text { observation }\end{array}$ & $\begin{array}{l}\text { Date } \\
\text { received }\end{array}$ & $\begin{array}{l}\text { Frequency } \\
\text { of Data }^{6}\end{array}$ & $\begin{array}{l}\text { Frequency } \\
\text { of } \\
\text { Reporting }^{6}\end{array}$ & $\begin{array}{l}\text { Frequency } \\
\text { of } \\
\text { Publication }\end{array}$ \\
\hline Exchange Rates & $11 / 27 / 06$ & $12 / 27 / 06$ & $\mathrm{D}$ and $\mathrm{M}$ & $\mathrm{D}$ and $\mathrm{M}$ & $\mathrm{D}$ and $\mathrm{M}$ \\
\hline $\begin{array}{l}\text { International Reserve Assets and Reserve } \\
\text { Liabilities of the Monetary Authorities }{ }^{1}\end{array}$ & $10 / 06$ & $11 / 06$ & M & $\mathrm{M}$ & M \\
\hline Reserve/Base Money & $10 / 06$ & $11 / 06$ & $\mathrm{M}$ & $\mathrm{M}$ & $\mathrm{M}$ \\
\hline Broad Money & $10 / 06$ & $11 / 06$ & M & M & $\mathrm{M}$ \\
\hline Central Bank Balance Sheet & $10 / 06$ & $11 / 06$ & M & $\mathrm{M}$ & $\mathrm{M}$ \\
\hline $\begin{array}{l}\text { Consolidated Balance Sheet of the Banking } \\
\text { System }\end{array}$ & $10 / 06$ & $11 / 06$ & M & M & M \\
\hline Interest Rates ${ }^{2}$ & $11 / 27 / 06$ & $11 / 27 / 06$ & $\mathrm{D}$ and $\mathrm{M}$ & $\mathrm{D}$ and $\mathrm{M}$ & $\mathrm{D}$ and $\mathrm{M}$ \\
\hline Consumer Price Index & $10 / 06$ & $11 / 06$ & $M$ & M & M \\
\hline $\begin{array}{l}\text { Revenue, Expenditure, Balance and } \\
\text { Composition of Financing }{ }^{3} \text {-General } \\
\text { Government }^{4}\end{array}$ & 2005 & $5 / 30 / 06$ & A & A & $A$ \\
\hline $\begin{array}{l}\text { Revenue, Expenditure, Balance, and } \\
\text { Composition of Financing }{ }^{3} \text {-Central } \\
\text { Government }\end{array}$ & 2005 & $5 / 30 / 06$ & A & A & $A$ \\
\hline $\begin{array}{l}\text { Stocks of Central Government and Central } \\
\text { Government-Guaranteed Debt }\end{array}$ & $10 / 06$ & $11 / 17 / 06$ & M & M & $\mathrm{M}$ \\
\hline External Current Account Balance & Q2 2006 & $10 / 06$ & Q & Q & M \\
\hline Exports and Imports of Goods and Services & Q2 2006 & $10 / 06$ & Q & Q & M \\
\hline GDP/GNP & Q2 2006 & $10 / 16 / 06$ & Q & Q & Q \\
\hline Gross External Debt & Q2 2006 & $10 / 06$ & Q & Q & Q \\
\hline
\end{tabular}

${ }^{1}$ Includes reserve assets pledged or otherwise encumbered as well as net derivative positions.

${ }^{2}$ Both market-based and officially-determined, including discount rates, money market rates, rates on treasury bills, notes and bonds.

${ }^{3}$ Foreign, domestic bank, and domestic nonbank financing.

${ }^{4}$ The general government consists of the central government (budgetary funds, extra budgetary funds, and social security funds) and state and local governments.

${ }^{5}$ Including currency and maturity composition.

${ }^{6}$ Daily (D), weekly (W), monthly (M), quarterly (Q), annually (A), irregular (I); and not available (NA). 


\section{INTERNATIONAL MONETARY FUND}

EXTERNAL

Public Information Notice

RELATIONS

DEPARTMENT

Public Information Notice (PIN) No. 07/26

FOR IMMEDIATE RELEASE

March 5, 2007

International Monetary Fund

$70019^{\text {th }}$ Street, NW

Washington, D. C. 20431 USA

\section{IMF Executive Board Concludes 2006 Article IV Consultation with Belgium}

On February 16, 2007, the Executive Board of the International Monetary Fund (IMF) concluded the Article IV consultation with Belgium. ${ }^{1}$

\section{Background}

The economic upturn that started in mid-2005 has remained on track. On the heels of a catchup in private investment, the revival of private consumption and the cyclical expansion in neighboring countries have broadened the recovery to all sectors of the economy. Underlying inflation has been stable and broadly in line with the euro area average. At odds with developments elsewhere in the euro area, the unemployment rate has not declined significantly. Comparatively faster labor force growth, high relative labor costs, and less wage moderation seem to be contributing factors. The real exchange rate has been appreciating, eroding competitiveness, and while exports shares have kept up well in value, they have declined in volume terms. Nonetheless, the current account has remained in surplus.

Despite some real exchange rate appreciation and interest rate hikes, monetary conditions have remained accommodating, only recently reaching their long-run average. Fiscal policy turned procyclical in 2006, imparting an impulse of almost 1 percentage point of GDP, as growth surprised on the upside. The 2007 budget aims for a surplus of 0.3 percent of GDP and a structural improvement of 0.6 percent of GDP. Recourse to one-off measures to reach budget

\footnotetext{
${ }^{1}$ Under Article IV of the IMF's Articles of Agreement, the IMF holds bilateral discussions with members, usually every year. A staff team visits the country, collects economic and financial information, and discusses with officials the country's economic developments and policies. On return to headquarters, the staff prepares a report, which forms the basis for discussion by the Executive Board. At the conclusion of the discussion, the Managing Director, as Chairman of the Board, summarizes the views of Executive Directors, and this summary is transmitted to the country's authorities.
} 
objectives is set to diminish, and primary spending growth will be slightly below GDP growth. Federal government spending is more restrictive, but regional authorities, which have little or no debt and an increasing share of revenue, are set to ramp up spending.

Against this background, economic growth is expected to slow but maintain a robust pace. The staff projects GDP growth to decline from nearly 3 percent in 2006 to 2.2 percent in 2007, as rising interest rates dampen demand, residential construction eases from its recent sustained vigorous pace, the fiscal stance turns restrictive, and the global environment softens. Over the long run, demographics are likely to lessen growth, and aging-related costs will add several percentage points of GDP to fiscal spending.

Benefiting from a benign risk environment, low interest rates and effervescent equity markets, financial enterprises are experiencing high returns. Banks remain well capitalized, and solvency and coverage ratios of insurance companies and pension funds have been rising. The internationalization of financial institutions has been accelerating, while banks are expanding in nontraditional areas and emerging markets. Households have been increasing their claims on institutional investors, and mortgage financing has been their largest source of credit. Corporate deleveraging is continuing.

In line with the 2005 Financial Sector Assessment Program (FSAP) recommendations, regulations and supervision in banking, insurance, securities, payments, and settlement have been fully aligned with international standards, pension fund and insurance supervision upgraded, and internal controls and operation of the supervisory agency improved.

On other structural issues, the upward trend in employment rates is set to continue, though it will contribute only two thirds of the long-term increase targeted by the authorities. The measures of the recently implemented Generation Pact will help to cover part of the remaining gap. Emphasis is being placed on activation and training policies. Marginal taxes on the high skilled have been cut, efforts to promote research and development bolstered, and the administrative burden on businesses and households reduced. The services sector is set to be subject to international competition in line with the EU directive.

\section{Executive Board Assessment}

Executive Directors commended the authorities on their sound fiscal and financial policies, and in particular, the significant fiscal consolidation which has allowed the economy to perform well and the financial sector to gain further resilience. They identified population aging and globalization as the key long-run challenges and expressed some concern about the recent erosion of competitiveness. Addressing these issues requires building up budget surpluses, moderating wage growth, and further improving education and the functioning of labor and product markets. To achieve these objectives in a timely manner, Directors called for a coordinated early and decisive policy response across all levels of government.

Directors noted that the pace of economic growth was expected to ease, but remain robust in 2007. They saw uncertainties surrounding this outlook associated with house price 
developments, external demand, and a possible euro appreciation. Directors agreed that the real effective exchange rate was broadly in line with fundamentals, but emphasized that competitiveness should not be allowed to erode further, which would require wage moderation and productivity-enhancing structural reforms.

Directors welcomed the strength and resilience of the financial sector. They commended the authorities on the major strides made in improving the already high quality of supervision, in line with the 2005 FSAP recommendations. Directors emphasized that there is a need to further improve cooperation between the supervisory agency (CBFA) and the central bank. They encouraged supervisors to focus on the rapid expansion of bank-insurance groups in nontraditional areas and other countries, which is changing the systemic risk profile of the financial system.

Directors welcomed the authorities' intentions to fully implement their multi-pronged approach to dealing with aging, consisting of fiscal adjustment and growth-enhancing reforms. In this context, Directors recommended a more ambitious path for fiscal consolidation, and considered that the authorities should lock in the structural adjustment and nominal surplus targeted in the 2007 budget, and the reduced recourse to one-off fiscal measures. Directors noted that further pension reforms would be essential, especially the phasing out of early retirement systems and the establishment of full actuarial fairness of the pension system. The growth of health care spending should be contained, building on recent progress in this area.

Directors observed that successful fiscal consolidation would require a revision to fiscal federalism arrangements and a strengthening of fiscal institutions. Though essentially a political matter, they underscored that in revising the revenue-sharing and allocation of spending responsibilities across levels of governments, accountability and coordination of fiscal and economic policies among federal and sub-federal entities would need to be strengthened, particularly as the fiscal objective shifts from balancing the budget to building up surpluses. Directors welcomed the resumption of the activities of the High Council of Finance and supported the authorities' intention to enhance the internal stability pact.

Directors felt that further labor market reforms, building on the steps taken in the Generation Pact, would be essential to lift employment rates and lower the costs of aging and encouraged the authorities to work on building the necessary consensus. They welcomed the sharpened focus on job search incentives and assistance, while recommending further streamlining and coordination of labor market policies across regions. They saw a need to lower the tax burden on labor, improve training, and reduce the generosity of out-of-work benefits. In particular, the duration of unemployment benefits would need to be limited in time. Over the medium term, Directors felt that the wage bargaining framework ought to be made more conducive to job creation, by taking better into account developments in productivity and employment rates in setting wages. They welcomed reforms in product markets, the reduction in the administrative burden, and the policies under way to promote innovation. Directors encouraged the authorities to accelerate the removal of obstacles to competition in the services sector. 
Public Information Notices (PINs) form part of the IMF's efforts to promote transparency of the IMF's views and analysis of economic developments and policies. With the consent of the country (or countries) concerned, PINs are issued after Executive Board discussions of Article IV consultations with member countries, of its surveillance of developments at the regional level, of post-program monitoring, and of ex post assessments of member countries with longer-term program engagements. PINs are also issued after Executive Board discussions of general policy matters, unless otherwise decided by the Executive Board in a particular case. The staff report (use the free Adobe Acrobat Reader to view this pdf file) for the 2006 Article IV Consultation with Belgium is also available. 


\section{Belgium: Selected Economic Indicators}

\begin{tabular}{lrrrrr}
\hline & 2003 & 2004 & 2005 & $20061 /$ & $20071 /$ \\
\hline Real economy (change in percent) & & & & & \\
$\quad$ Real GDP & 1.0 & 2.7 & 1.5 & 2.9 & 2.2 \\
$\quad$ Domestic demand & 0.9 & 2.9 & 2.1 & 2.7 & 1.7 \\
CPI & 1.5 & 1.9 & 2.5 & 2.4 & 1.9 \\
$\quad$ Unemployment rate (in percent) & 8.2 & 8.4 & 8.4 & 8.3 & 8.1 \\
Public finance (percent of GDP) & & & & & \\
$\quad$ General government balance & 0.0 & 0.0 & -2.3 & 0.0 & 0.0 \\
$\quad$ General government balance excluding Eurostat & & & & & \\
$\quad$ adjustment 2/ & 0.0 & 0.0 & 0.1 & 0.0 & 0.0 \\
$\quad$ Structural balance & -0.8 & -0.7 & 0.2 & -0.7 & -0.4 \\
$\quad$ Primary balance & 5.4 & 4.7 & 2.0 & 4.1 & 3.9 \\
$\quad$ General government debt & 98.6 & 94.4 & 91.5 & 87.4 & 84.1 \\
Interest rates (percent) & & & & & \\
$\quad$ Money market rate (3 months) & 2.3 & 2.1 & 2.2 & 3.0 & $\ldots$ \\
$\quad$ Government bond yield & 4.2 & 4.1 & 3.4 & 3.8 & $\ldots$ \\
Balance of payments (percent of GDP) & & & & & \\
$\quad$ Trade balance & 3.5 & 2.7 & 1.6 & 1.2 & 1.4 \\
$\quad$ Current account & 4.1 & 3.5 & 2.5 & 2.4 & 2.7 \\
$\quad$ Official reserves (US\$ billion) & 11.0 & 10.4 & 8.2 & 8.1 & \\
Exchange rate & & & & & \\
$\quad$ Exchange rate regime & & & Member of EMU & \\
$\quad$ Euro per U.S. dollar (January 4, 2006) & & 0.76 & & & \\
$\quad$ Nominal effective rate (2000=100, ULC based) & 101.6 & 105.7 & 106.8 & 106.9 & \\
$\quad$ Real effective rate (2000=100, ULC based) & 104.8 & 109.4 & 111.8 & 113.8 & \\
\hline
\end{tabular}

Sources: Data provided by the Belgian authorities; and IMF staff projections.

$1 /$ IMF staff estimates and projections.

2/ According to Eurostat, the debt transfer of the national railway company to the Railway Infrastructure Fund should be accounted as expenditure in 2005. 